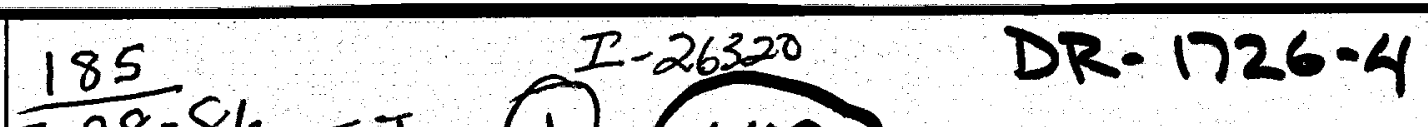

BNL 51960

\title{
CHARACTERISTICS OF HIGH TEMPERATURE CEMENTITIOUS LOST-CIRCULATION CONTROL MATERIALS FOR GEOTHERMAL WELLS
}

T. Sugama, L.E. Kukacka, B.G. Galen, and N.B. Milestone

January 1986

PROCESS SCIENCES DIVISION

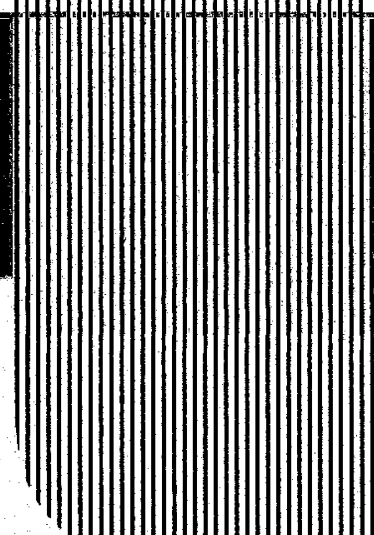

\section{CO NOT MICROHLIVI COVER}

DISTRIBUTION OF THIS DOCUNENT IS UHLIGIEA

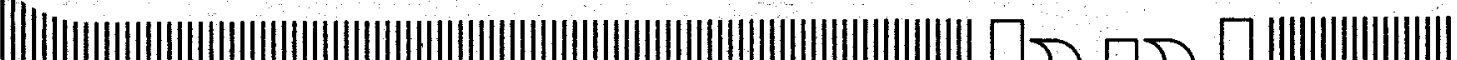




\section{DISCLAIMER}

This report was prepared as an account of work sponsored by an agency of the United States Government. Neither the United States Government nor any agency Thereof, nor any of their employees, makes any warranty, express or implied, or assumes any legal liability or responsibility for the accuracy, completeness, or usefulness of any information, apparatus, product, or process disclosed, or represents that its use would not infringe privately owned rights. Reference herein to any specific commercial product, process, or service by trade name, trademark, manufacturer, or otherwise does not necessarily constitute or imply its endorsement, recommendation, or favoring by the United States Government or any agency thereof. The views and opinions of authors expressed herein do not necessarily state or reflect those of the United States Government or any agency thereof. 


\section{DISCLAIMER}

Portions of this document may be illegible in electronic image products. Images are produced from the best available original document. 


\title{
DISCLAIMER
}

\footnotetext{
This report was prepared as an account of work sponsored by an agency of the United States Government. Neither the United States Government nor any agency thereof, nor any of their employees, makes any warranty, express or implied, or assumes any legal liability or responsibility for the accuracy, completeness, or usefulness of any information, apparatus, product, or process disclosed, or represents that its use would not infringe privately owned rights. Reference herein to any specific commercial product, process, or service by trade name, trademark, manufacturer, or otherwise does not necessarily constitute or imply its endorsement, recommendation, or favoring by the United States Government or any agency thereof. The views and opinions of authors expressed herein do not necessarily state or reflect those of the United States Government or any agency thereof.
}

\section{CHARACTERISTICS OF HIGH TEMPERATURE CEMENTITIOUS LOST-CIRCULATION CONTROL MATERIALS FOR GEOTHERMAL WELLS}

T. Sugama, L.E. Kukacka, B.G. Galen, and N.B. Milestone

January 1986

\author{
Meyer Steinberg \\ PROCESS SCIENCES DIVISION \\ DEPARTMENT OF APPLIED SCIENCE \\ BROOKHAVEN NATIONAL LABORATORY \\ ASSOCIATED UNIVERSITIES, INC.
}

This work performed

under the auspices of the Geothermal Technology Division,

United States Department of Energy, Washington, DC, under contract No. DE-ACO2-76CH0OO16

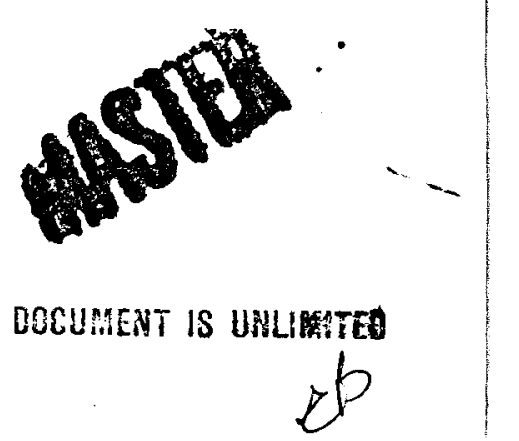




\section{DISCLAIMER}

This report was prepared as an account of work sponsored by an agency of the United States Government. Neither the United States Government nor any agency thereof, nor any of their employees, nor any of their contractors, subcontractors, or their employees, makes any warranty, express or implied, or assumes any legal liability or responsibility for the accuracy, completeness, or usefulness of any information, apparatus, product, or process disclosed, or represents that its use would not infringe privately owned rights. Reference herein to any specific commercial product, process, or service by trade name, trademark, manufacturer, or otherwise, does not necessarily constitute or imply its endorsement, recommendation, or favoring by the United States Government or any agency, contractor or subcontractor thereof. The views and opinions of authors expressed herein do not necessarily state or reflect those of the United States Government or any agency, contractor or subcontractor thereof.

Printed in the United States of America Available from

National Technical Information Service

U.S. Department of Commerce

5285 Port Royal Road

Springfield, VA 22161

NTIS price codes:

Printed Copy: A03; Microfiche Copy: A01 


\section{SYYNOPSIS}

Materials systems have been formulated for the in situ conversion of water-based bentonite drilling fluids into cementitious lost-circulation control materials (CLCM) for use in geothermal wells at temperatures up to $300^{\circ} \mathrm{C}$. The formulations consist of a cement hardener, a borax admixture, and a fiber glass bridging material which are added to the bentonite fluids. Evaluations of the properties of the slurry and the cured CLCMs revealed that the lons supplied by dissociation of the borax in the CLCM slurry acted to suppress the bentonite hydration and retarded the hardening rate of the cement at elevated temperatures. The $\mathrm{CaO}-\mathrm{S}_{10} \mathrm{O}_{2}-\mathrm{H}_{2} \mathrm{O}(\mathrm{C}-\mathrm{S}-\mathrm{H})$ phases formed during curing of the CLCM play essential roles in Improving the quality of the hardened CLCMs. It was observed that xonotlite-truscottite transformations resulted in strength reductions and increased water permeability. The plugging ability of fiber glass depends on the concentration and fiber size. The silicate lons dissolved by hot alkaline disintegration of the fiber glass were chemisorbed with $\mathrm{Ca}^{2+}$ lons from the cement and led to the precipitation of C-S-H compounds on the fiber surfaces, which improved bond strength at the matrix-fiber interfaces. 


\section{INTRODUCTION}

Ideally, it should be possible to solve lost-circulation problems in geothermal wells by the direct addition to water-based drilling fluids of a material that forms a slurry, which is pumpable a hydrothermal conditions up to $300^{\circ} \mathrm{C}$, and thus can be circulated to a formulation in which loss of fluid occurs. In addition, the material should be capable of converting the drilling mud into a hardened mass which has adequate strength within approximately two hours after plugging the cavernous and highly fractured zones. It has been estimated that the solidified material must have the following minimum characteristics at $300^{\circ} \mathrm{C}$ to act as an effective seal in a cementitious lost-circulation control material (CLCM)1: (1) compressive strength $>3.45 \mathrm{MPa}$ (500 psi) at an autoclaving age of two hours, (2) permeability to water <1 $\times 10^{-2}$ darcys, and (3) an increase in volume upon curing.

In oil wells in which the bottom hole temperature never exceeds $150^{\circ} \mathrm{C}$, conventional portland cements are frequently used for lost-circulation control materials.2 This is convenient since cement is readily available at all well sites. Unfortunately, the common cement plugging systems, which consist of perlite, cement, and silica flaur, of ten give unsatisfactory results, particularly on the first attempt, primarily because the downhole temperature is not known accurately enough to determine the needed amount of retarder. ${ }^{3}$

Diesel oll-bentonite-cement gunk squeezes ${ }^{4-6}$ are used successfully by the petroleum industry to control total lost circulation, but not generally in geothermal drilling because of environmental objections to the diesel ofl component. 7

The use of the sodium silicate, which is environmentally acceptable, is very attractive since cementing equipment and cement placement procedures are not needed with this method. The sodium silicate gel is generally pumped Into the lost-circulation zone ahead of the cement to form a barrier which retains the slurry while it sets. Unfortunately, as with the conventional portland cement systems, difficulties arise at temperatures $>2000^{\circ} \mathrm{C} .7$ 
The direct addition of conventlonal portland cement to a highly concentrated bentonite drilling fluid produces a lower-strength material. This is considered to be due to the strongly thixotropic gel and swelling of the bentonite hydration products brought about by chemisorption of the free water in the neat cement pastes. Hence, the disadvantage of commercial cement-bentonite-water systems for utilization as CLCMs include the lack of knowledge on the actual degree of bentonite hydration, and the difficulty of mixing the thick slurry into: the active mud systems. Nevertheless, the use of hydraulic cement as a sealing agent offers the following advantages; (1) wide availability, (2) ease of direct addition to water-based drilling fluid, and (3) relatively low cost.

The current Brookhaven National Laboratory (BNL) effort emphasized the development of cement-based sealing systems that can be added directly to the conventional water-based bentonite fluids. The goal was to identify cementitious sealing systems that when added to hydraulic cement will have controllable setting times and will develop adequate mechanical strength after exposure to temperatures up to $300^{\circ} \mathrm{C}$. Therefore, the first part of the research was to select a retarding admixture that could be used in conjunction with the conventional cement formulations to yield a CLCM, which meets the above criteria. The desired admixture would also have to be effective in improving the controllability of the bentonite hydration as well as expansion of the CLCM upon curing.

Inorganic-type admixtures, which are not susceptible to hydrothermal disintegration at high temperatures, were employed in this study. Types of materials considered Included chlorine, sodium sillcate, sodium phosphate, and boron compounds. The reaction products formed during autoclave exposure of the CLCM in the presence of the most sultable admixture, and the CaO-S1O $-\mathrm{H}_{2} \mathrm{O}$ formations which are primarily responsible for 8 treng th development at elevated temperatures, were identified by means of $x$-ray powder diffraction (XRD) and scanning electron microscopy (SEM).

Although it is expected that a pumpable CLCM could easily penetrate Into a wide size range of lost-circulation zones, it is probable that a large amount of the cementing slurry would be lost into large-sized 
fractures before the setting of the CLCM. Therefore, screening tests using commerclally available bridging materials which were added to the CLCMs were also performed in an attempt to enhance sealing and improve the mechanical properties of the hardened plug.

\section{EXPERIMENTAL}

The general properties of a standard drilling fluid consisting of $6 \%$ Wyoming bentonite, supplied by NL Baroid, Inc., and $94 \%$ water, as measured using a Model 35 A Fann Direct Indicating Viscometer, are given below:

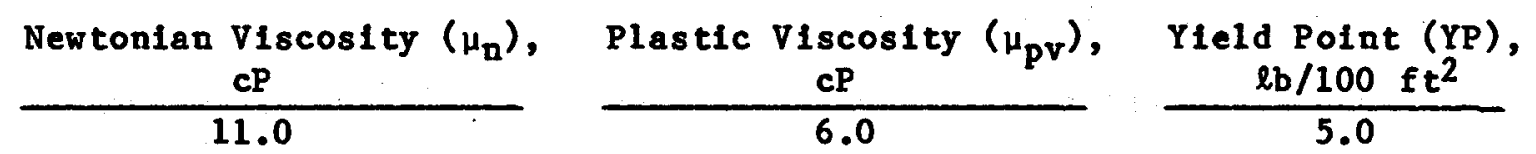

$\mu_{n}$ was computed using the following formula;

$$
\mu_{n}=300 \frac{\theta}{N},
$$

where $\theta$ is the Fann viscometer reading, and $N$ ( $\mathrm{rpm}$ ) is the rotation rate of the outer cylinder. $\mu_{p v}$, which represents a fineness specification for solid dispersions in an aqueous medium, was obtained from the difference between the values of the viscometer readings at 600 and $300 \mathrm{rpm}$. The yield point (YP), expressed as $1 b / 100 \mathrm{ft}^{2}$, represents the magnitude of clay activity created primarily by the charged surfaces and is given as follows:

$$
\mathrm{YP}=\theta_{300}-\mu_{\mathrm{pv}}
$$

The value of $11.0 \mathrm{cP}$ for the Newtonian viscosity which was measured for the standard fluld, corresponds to the value specified in American Petroleum Institute (API) Standard $13 A$.

API class $H$ and class $J$ cements were used as the matrix for the CLCMs, since they have good strength characteristics at bottom-hole static temperatures $>110^{\circ} \mathrm{C}$. Typical chemical analyses of the class $\mathrm{H}$ and class $\mathrm{J}$ cements that were supplied by the Lehigh Portland Cement Company are given below. 


\section{Composition, wt\%}

$\begin{array}{llllllll}\text { Class H } & \frac{\mathrm{SlO}_{2}}{22.40} & \frac{\mathrm{CaO}}{64.40} & \frac{\mathrm{Al}_{2} \mathrm{O}_{3}}{4.29} & \frac{\mathrm{Fe}_{2} \mathrm{O}_{3}}{4.92} & \frac{\mathrm{MgO}}{0.80} & \frac{\mathrm{SO}_{3}}{2.20} & \frac{1 \text { Loss on }}{\text { Ignition }} \\ \text { Class } \mathrm{J} & 50.97 & 40.68 & 0.86 & 0.70 & 1.01 & 0.29 & 4.75\end{array}$

Class $\mathrm{J}$ is a silica-lime cement system that is not described by an API chemical specification. Unlike other API cements, class $J$ does not require additional silica to prevent strength retrogression at temperatures above $110^{\circ} \mathrm{C}$. As a result, reactive silica flour having a particle size $<44$ mm was added to only the class $H$ cement system. This system consisted of 60 parts cement to 40 parts silica flour.

The specimens were prepared according to the following procedures. First the bentonite fluids were thoroughly mixed with the proper amount of the various cement retarding admixtures. The class $\mathrm{J}$ and class $H$ cement systems were then incorporated into the chemically treated fluids, and subsequently mixed using a Hamilton Beach Mixer. The CLCM mixes used in these studies were composed of $60 \%$ treated fluid, $24 \%$ cement, and $16 \%$ silica flour for the class H cement-based systems, and $60 \%$ treated fluid, $40 \%$ cement for the class $\mathrm{J}$ systems. The density of both slurries was $\sim 1.45 \mathrm{~g} / \mathrm{cm}^{3}$ as determined with a Baroid Four Scale Mud Balance. The assumption that the pluggIng materials will have to be placed into water-filled fractures, all the CLCM slurries were placed into water-filled test tubes and maintained at room temperature until the slurry settled completely to the bottom of the aqueous media. After settling, the slurry-filled test tubes were exposed in an autoclave for two hours at temperatures up to $300^{\circ} \mathrm{C}$.

\section{RESULTS AND DISCUSSION}

\section{Admixtures}

A search was conducted to identify admixtures that would yield a slurry pumpable at elevated temperatures, which, upon curing, would have the required strength characteristics. In this work, the various inorganic chemical compounds listed in Table 1 were evaluated on the basis of their changes 
In viscosity and the thickening temperature for the CLCM slurry, and the resul tant compressive strength after curing for two hours in an autoclave at $300^{\circ} \mathrm{C}$. The viscosities were measured using a Fann Direct Indicating Viscometer, Model 35A. The thickening temperature mbasurements were made using a 7.5-cm-diam $\times 23.8-\mathrm{cm}-1$ ong stirred autoclave in a maner similar to that reported earlier. 1

The CLCM formulation employed in this series of experiments was composed of 60 parts bentonite fluid ( $6 \%$ bentonite - $94 \%$ water) and 40 parts class $J$ cement. The admixtures were added directly to the bentonite mud before mixing the class $J$ cement. It should be noted that all reported admixture concentrations are by weight of the bentonite-cement mix slurry. All the chemical agents were supplied by the Fisher Scientific company, except for the commercial-grade boron compounds, which were obtained from the United States Borax Chemical Corporation.

Data from this series of tests are summarized in Table 1 . In the absence of any admixtures, the control slurries had a viscosity of $135 \mathrm{cP}$, a thickening temperature of $\sim 160^{\circ} \mathrm{C}$, and a compressive strength of $2.27 \mathrm{MPa}$ (329 psi) at an age of two hours. The relatively high viscosity results in the formation of a thixotropic gel of bentonite hydration caused by chemisorbing the water in the neat cement pastes. As result, the onset of setting is at a relatively low value of $\sim 160^{\circ} \mathrm{C}$. The data al so indicate that the addition of admixtures which are soluble in the alkaline bentonite fluid reduces the viscosity and increases the thickening temperature of the slurries. All the admixtures used in this study appear to be hydrolyzed by the alkaline solution to dissociate uni-, di-, and trivalent lons, and these lons act to inhibit the rates of bentonite and cement hydrations. It appears from the data that univalent cations such as $\mathrm{Na}^{+}$and $\mathrm{H}^{+}$are more effective in reducing the slurry consistency at $24^{\circ} \mathrm{C}$ than are the di- and trivalent cations such as $\mathrm{Ca}^{2+}, \mathrm{Ba}^{2+}$, and $\mathrm{Al}^{3+}$. For example, slurries containing $\mathrm{AlCl}_{3}$ and $\mathrm{CaCl}_{2}$ had viscosities ranging from 93 to $100 \mathrm{cP}$, while those containing sodium phosphate, sodium borate compounds, and boric acid had values from 70 to $35 \mathrm{cP}$. Of the various univalent cation-dissoclating admixtures tested, sodium phosphate anhydrate $\left(\mathrm{Na}_{3} \mathrm{PO}_{4}\right)$ was the most effect- 
Ive in reducing the viscosity of the control slurry. With a $5 \%$ concentration of $\mathrm{Na}_{3} \mathrm{PO}_{4}$, the viscosity was $35 \mathrm{cP}, \sim 74 \%$ less than that of the control. Slurry viscosities ranging between 70 and $62 \mathrm{cP}$ can be obtained by adding a 7\% concentration of anhydrous and hydrated sodium tetraborate reagents.

The thickening temperature for the slurries is also dramatically raised with an Increase in the $\mathrm{Na}_{3} \mathrm{PO}_{4}$ admixture concentration. The thickening temperature of the control was extended to $>300{ }^{\circ} \mathrm{C}$ by the addition of $7 \% \mathrm{Na}_{3} \mathrm{PO}_{4}$, but unfortunately the 2-hr compressive strength for the cured formulation was too $10 \mathrm{w}$ to be measured. Reducing the $\mathrm{Na}_{3} \mathrm{PO}_{4}$ concentration to $0.5 \%$ did not result in strength improvements. Similar results were obtained from specimens containing the boric acid admixture. It is speculated that $\mathrm{Na}_{3} \mathrm{PO}_{4}$ and $\mathrm{H}_{3} \mathrm{BO}_{3}$ admixtures which liberate large numbers of $\mathrm{PO}_{4}{ }^{3-}$ and $\mathrm{BO}_{3}{ }^{3-}$ Ions as the counterions of $\mathrm{Na}^{+}$and $\mathrm{H}^{+}$indefinitely retard the setting and hardening of hydraulic cement at temperatures up to $300^{\circ} \mathrm{C}$.

The best admixtures for retarding the hydration of the cement but yet meeting the early strength criteria were the borax compounds such as borax $10 \mathrm{~mol}$, borax $5 \mathrm{~mol}$, and anhydrous borax. Of these varlous borax additives, the borax $10 \mathrm{~mol}$ gave the greatest enhancement in thickening temperatures and compressive strength. Specimens containing $7 \%$ of the borax 10 mol exhibited a thickening temperature of $280^{\circ} \mathrm{C}, 120^{\circ} \mathrm{C}$ over that of the control, and the autoclaved specimens had a 2 -hr strength of $1.93 \mathrm{MPa}(280 \mathrm{psi})$. A further increase in the borax concentration up to $10 \%$ resulted in an appreclable strength reduction.

The ability of $\mathrm{Na}^{+}$and $\mathrm{B}_{4} \mathrm{O}^{2-}$ ions released by dissolution of the borax 10 mol to Improve the controllability of the hydration distribution of bentonite-cement composite systems is of particular interest. Since the borax admixtures were usually added to the bentonite flulds before mixing the cement, the chemical affinity between the dissoclated lons and the bentonite muds was studied first. Reasons for these lons acting to retard the hardening rate of the cements were then investigated. The experimental work was performed in accordance with the following procedures: $100 \mathrm{~g}$ of the bentonite fluid were placed in a $300-\mathrm{ml}$ glass beaker and $7 \mathrm{~g}$ of the borax 10 mol were then added to the fluid. The beaker was then sealed and the fluids 
were mixed at room temperature for up to 24 hours. The aqueous phase was then extracted by a centrifugal separation. Concentrations of $\mathrm{Na}^{+}, \mathrm{B}_{4} \mathrm{O}_{7}{ }^{2-}$; and silicate ions in the extracted liquids were then determined using Atomic Absorption Spectrophotometry (AA) and High Performance Anion Chromatography (HAC). X-ray powder diffraction analyses (XRD) with CuKa radiation were also performed on treated bentonite fluids that were exposed in the autoclave at $300^{\circ} \mathrm{C}$ for 2 hours, and then dried. These data yield information regarding the reaction products formed by the autoclaving.

As shown in Figure 1, the amount of $\mathrm{Na}^{+}$ions in solution increases with mixing time until the concentration reaches a peak value of $\sim 4.3 \times 10^{-1}$ mole/ $l$ after $\sim 300 \mathrm{~min}$. The concentration than decreases gradually to $\sim 3.5 \times$ $10^{-1}$ mole/ $l$ after $1440 \mathrm{~min}$. In contrast, the $\mathrm{B}_{4} \mathrm{O}_{7}{ }^{2-}$ reached a maximum concentration of $\sim 1.9 \times 10^{-1}$ mole/ $l$ within $\sim 300 \mathrm{~min}$ and then remained constant. This implies that the fluids became saturated with both lons during a mixing period of $\sim 300 \mathrm{~min}$. In contrast the concentration of silicate lons dissociated from the montmorillonite tends to increase with elapsed time, ranging from $4.5 \times 10^{-4}$ moles $/ l$ after $10 \mathrm{~min}$ to $3.1 \times 10^{-3}$ moles $/ \ell$ after $1440 \mathrm{~min}$. These values are approximately two orders of magnitude less than those for $\mathrm{Na}^{+}$and $\mathrm{B}_{4} \mathrm{O}_{7}^{2-}$.

The structure of anhydrous montmorillonite which consists of a $\left[\mathrm{Al}_{2}\left(\mathrm{OH}_{4}\right)\right] \mathrm{n}^{2 \mathrm{n}}$ sheet layer sandwiched between two $\left(\mathrm{Si}_{2} \mathrm{O}_{5}\right) \mathrm{n}^{2 \mathrm{n}}$ - sheet layers, is composed of superposed lamellae which have an edge absorption at a diffuse negative silica sheet with various cations balancing unsaturated oxygen lons at the edges of the crystal lattice of the lamellae. It was well known9-11 that the negative charge arising on this layer as the result of the substitution is balanced by chemisorption of cations such as $\mathrm{H}^{+}, \mathrm{Na}^{+}$, $\mathrm{K}^{+}, \mathrm{Ca}^{2+}, \mathrm{Mg}^{2+}$, and $\mathrm{Al}^{3+}$ lons located between the sheets together with molecules of water. The XRD patterns of the dried borax treatment montmorillonites were characterized by strong lines at $17.7,4.41$, and $3.29 \AA$, and medium intensities at 3.58 and $3.11 \AA$. These spacings can be ascribed to the Na-saturated montmorillonite hydrate formed by. hydrothermal reactions between the negatively charged silicate plates of montmorillonite 
and the $\mathrm{Na}^{+}$lons liberated from the borax. 12 The $\mathrm{Na}^{+}$lons are more $11 \mathrm{kely}$ to be chemisorbed onto the cation-absorbing silicate surface of montmorillonite by proceeding to neutralization, rather than to the dissolved silicate ions. The $\mathrm{B}_{4} \mathrm{O}_{7}{ }^{2-}$ Ions which are substantially inert to $\mathrm{S1-0}$ - surfaces remain as a reactive ion species in the bentonite fluids.

On the basis of the above experiments, it is possible to speculate on possible interaction mechanisms between the $\mathrm{Na}^{+}$lons and the hydrated montmorillonite sheet layers as follows: when the bentonite powder is mixed with water, the diffuse negative silica sheets at the edges of the montmorillonite crystal lattice strongly chemisorb large numbers of water molecules to initiate the hydration of bentonite. Simultaneously, silicate ions are released from the montmorillonite surfaces. This separation between the clay plates that is brought about by water adsorption of bentonite plays an essential role in increasing the fluid viscosity, resulting in the swelling of the bentonite. Both the $\mathrm{Na}^{+}$and $\mathrm{B}_{4} \mathrm{O}_{7}{ }^{2-}$ Ions dissociate immediately after the addition of the borax to the hydrated bentonite fluids, and the maximum concentrations of these lons in the fluids occur within $300 \mathrm{~min}$. Subsequently, the $\mathrm{Na}^{+}$which can be expressed in terms of the compensation lons, is chemisorbed on the S1-0- located between the intersheets. Once the negative silica sheets are neutrally balanced by the compensative $\mathrm{Na}$ tons, the water-adsorbing capacity of the interlayers becomes very small. These $\mathrm{Na}^{+}$ ion-saturated intersheets lead directly to reductions in the consistency of the bentonite fluid as a result of the reduced swelling of the bentonite. Hence, when hydraulic cement is introduced Into the neutralized bentonite particles, the rate of thixotropic gel formation of the bentonite flufd caused by chemisorption of the water existing in the neat cement pastes is considerably lower.

On the other hand, the effect of $\mathrm{B}_{4} \mathrm{O}_{7}{ }^{2-}$ lons on the retardation of setting cement was studied on the basis of results from slurry samples prepared by mixing class $J$ cement with the borax-treated bentonite fluid. For the analysis of $\mathrm{Ca}^{2+}, \mathrm{B}_{4} \mathrm{O}^{2-}$, and sil lcate lons at a given mixing time, the aqueous phase was extracted using a centrifugal separator, and the 
concentration of these lons was then determined using $A A$ and HAC. The bentonite-cement mix slurries contalned a treated bentonite fluid/cement ratio of 3.06 . For purposes of comparison with the changes in the dissociated $\mathrm{Ca}^{2+}$ and silicate lons in the bentonite-borax-cement-water systems, lonic concentration analyses of ordinary class $J$ ćement pastes having a water/cement ratio of 2.69 were also performed.

The analyzed results for dissolved $\mathrm{Ca}^{2+}, \mathrm{B}_{4} \mathrm{O}_{7}^{2-}$, and silicate lons from these material systems are shown in Figure 2. In the liquid phase of neat cement pastes, the concentration of $\mathrm{Ca}^{2+}$ increases with stirring time until a concentration of $\sim 2.6 \times 10^{-2}$ mole/ $l$ is reached after $200 \mathrm{~min}$. After that it decreases slowly. The quantitative level of silicate lons dissociated from the cement is extremely low, typically two orders of magnitude less than that of $\mathrm{Ca}^{2+}$. The observation is in agreement with the results given by several other investigators.13-15

Compared to the $\mathrm{Ca}^{2+}$ or $\mathrm{Si}$ concentration vs stirring time relation for the cement paste systems, very different curves were obtained for the bentonite-borax-cement-water slurry systems. For example, the $\mathrm{Ca}^{2+}$ Ion concentration in the aqueous phase of the cement-bentonite slurry systems was only $3.2 \times 10^{-5}$ mole/ $l$ after $10 \mathrm{~min}$. This is approximately three orders of magnitude lower than that for the cement paste systems. This extremely low level of $\mathrm{Ca}^{2+}$ dissolution in the induction period for cement hydration is probably due to a rapid adsorption of $\mathrm{B}_{4} \mathrm{O}_{7}{ }^{2-}$ counterions by the $\mathrm{Ca}^{2+}$ ions which form the positively charged surface of hydrating cement grains. The concentration of $\mathrm{B}_{4} \mathrm{O}_{7}{ }^{2-}$ lons with time, therefore, tends to decrease as the concentration of $\mathrm{Ca}^{2+}$ lons increases. The quantity of silicate lons should be the sum of the lons dissolved from the bentonite (see Figure 1 ) and the cement grains (shown in Figure 2). However, the values between 10 and 300 min are appreciably higher than the sum of values obtained from the individual cement paste and bentonite-borax fluid systems. Although there is some discrepancy in the total quantity of soluble silicate species, the curve indicates that the silicate lons reach a peak concentration of $2.0 \times 10^{-3}$ mole/l after a stirring time of $300 \mathrm{~min}$, and then drops to $1.6 \times 10^{-3} \mathrm{~mole} / \mathrm{l}$ after $1440 \mathrm{~min}$. 
In an attempt to develop correlation between the $\mathrm{Ca}^{2+}, \mathrm{B}_{4} \mathrm{O}_{7}^{2-}$, and silicate ion dissolutions, the changes in riscosity and $\mathrm{pH}$ of the slurry samples were plotted againt the stirring time. As seen in Figure 3, the viscosity of the slurry increases gradually for $\sim 100 \mathrm{~min}$ after the cement Is added to the borax-treated bentonite fluids, and then rapidly rises. Similar trends were obtained for the $\mathrm{pH}$ values. The rapid increase in viscosity and $\mathrm{pH}$ after $\sim 200 \mathrm{~min}$ is due to the increased precipitation of colloidal calcium silicate hydrate ( $\mathrm{CSH}$ ) formed in the vicinity of the cement grains. Th1s would be assoclated with the previously discussed peak concentration of silicate lons after $\sim 300 \mathrm{~min}$.

From the above information, a possible explanation for the retarding activity of $\mathrm{B}_{4} \mathrm{O}_{7}{ }^{2-}$ lons is as follow: when mixed with bentonite fluid, borax appears to be hydrolyzed by the alkaline solution to liberate $\mathrm{B}_{4} \mathrm{O}_{7}{ }^{2-}$ lons which act as $\mathrm{Ca}^{2+}$ cation-accepting anions. After the addition of cement powder, the $\mathrm{B}_{4} \mathrm{O}_{7}{ }^{2-}$ lons react rapidly with $\mathrm{Ca}^{2+}$ lons released from the cement grains in the colloidal bentonite-borax-cement-water phase. This reaction with $\mathrm{Ca}^{2+}$ ions results in the precipitation of a calcium-depleted silica gel and the conversion into an semipervious film of $\mathrm{Ca}^{2+}-\mathrm{B}_{4} \mathrm{O}^{2-}$ compounds covering the cement graln surfaces. Al though the cement-retarding mechanisms are due to either the precipitation or the conversion membrane coating, these effects are thought to delay the nucleation processes of $\mathrm{C}-\mathrm{S}-\mathrm{H}$ gel formation and to provide an effective barrier to the further hydration reaction between the cement and water until it is gradually destroyed by calcium dissociated from the cement paste. The precipitation of a colloldal C-S-H gel produced by the lonic reaction between the Ca2t In solution and the hydrolyzed silicate-rich surface of the cement grains is $11 \mathrm{kely}$ to begin after $100 \mathrm{~min}$ hydration. It appears that the hydrolyzed products of borax have a moderate ability to bind the calcium lons 1 n alkaline bentonite flulds.

Consequently, the borax $10 \mathrm{~mol}$ admixture appears to have a high potential for use as an inhibitor for both the bentonite and the cement hydration in these specific CLCM systems. The key element governing the retarding functions was found to be the hydrolytically degraded products of the borax. 
Further information regarding the ability of borax to retard the setting of cement is given in Figure 4. Data for the thickening time of bentonite-cement-water slurry systems as a function of temperature and borax concentration are given. The major aim in this test was to gain information regarding the actual workability of the bentonite-borax-water class $H$ and class $\mathrm{J}$ cement systems at hydrothermal temperatures of $200^{\circ} \mathrm{C}, 250^{\circ} \mathrm{C}$, and $300^{\circ} \mathrm{C}$, under a pressure of $10.34 \mathrm{MPa}(1500 \mathrm{ps} 1)$. At $200^{\circ} \mathrm{C}$, the lowest temperature investigated, the thickening time for non-borax-containing bentonite class $H$ or $J$ slurry systems was too short to be measured. The workability of the class $H$ and class $J$ systems was dramatically extended to $\sim 145 \mathrm{~min}$ and $\sim 80 \mathrm{~min}$, respectively, by the addition of $3 \%$ borax. A further increase in borax concentration to $7 \%$ extended the thickening times for both systems to $\geq 200 \mathrm{~min}$. Similar trends were noted for slurry specimens at $250{ }^{\circ} \mathrm{C}$ and $300^{\circ} \mathrm{C}$. However, at a temperature of $300^{\circ} \mathrm{C}$, the workability of the class $\mathrm{J}$ system containing $7 \%$ borax could not be measured because of the rapid hardening.

It is also evident from Figure 4 that the thickening times for the borax-treated class $H$ systems are longer than for the class $J$ systems. Thus, the proper cholce of cement is likely to be one of the key factors associated with extending the thickening times for CLCMs. Since the CLCMs must be capable of safely accommodating interruptions in pumping operations due to mechanical trouble, or if regions of unpredictably high geothermal temperature are encountered, it is assumed that the required thickening times should be at least $100 \mathrm{~min}$. For the class $\mathrm{H}$ systems in the $2000^{\circ} \mathrm{C}$ to $250^{\circ} \mathrm{C}$ range, the addition of $\sim 7.0 \%$ borax meets this criterion. Unfortunately, at $300^{\circ} \mathrm{C}$ the thickening time was only $\sim 15 \mathrm{~min}$. Therefore, further work in which the borax-based composite system is used in conjunction with other boron-type reagents is necessary before the CLCM can be considered for placement at temperatures $\geq 300^{\circ} \mathrm{C}$.

It was also found that the borax is effective as a swelling agent. Although it is not shown in the figures or the tables, the linear expansion increased with the amount of borax up to a concentration of $7 \%$. Specimens 
without borax exhiblted a shrinkage of $\sim 1.6 \%$ after exposure for 2 hr at $300^{\circ} \mathrm{C}$. Formulations contalning $3 \%$ and $7 \%$ borax showed expansions of $\sim 1.9 \%$ and $\sim 2.2 \%$, respectively. This slight expansion characteristic might help to yield an effective seal after placement.

Effect of C-S-H on Compressive Strength and Water Permeability

Tests were performed to determine if changes in the compressive strength and water permeability of borax-modified CLCMs occur upon continued exposure in an autoclave. In this work, bentonite class $\mathrm{H}$ and class $\mathrm{J}$ slurry systems containing $7 \%$ borax were cast into $3.5-\mathrm{cm}-\mathrm{diam}$ by $7.0-\mathrm{cm}-1$ ong glass tubes for use in compressive strength measurements, and in 3.0-cm-diam by $4.0-\mathrm{cm}$-thick tubes for water permeability tests. The specimens were then exposed in an autoclave for up to 10 days at temperatures of $2000,250^{\circ}$, and $300^{\circ} \mathrm{C}$. The data were then correlated with the phase analyses of reaction products identifled using XRD and the morphological features of the crystal forms using scanning electron microscopy (SEM).

The compressive strength and water permeability results are shown in Figures 5 and 6 , respectively. Phases detected by XRD in several specimens are summarized in Table 2. It was found that at $300^{\circ} \mathrm{C}$ the compressive strength of class H cement composites increased with exposure time up to $\sim 24 \mathrm{hr}$. At this age, a strength of $3.3 \mathrm{MPa}$ (479 ps1) was developed. Continued autoclave exposure resulted in strength reductions. The water permeability exhibited an Initial decrease, reaching a minimum at $\sim 6 \mathrm{hr}$. It then gradually increased. However, after 10 days the permeability was still at a satisfactory value of $5.7 \times 10^{-4}$ darcys.

The results from XRD analyses revealed dramatic changes in the phases of the $\mathrm{C}-\mathrm{S}-\mathrm{H}$ compounds formed as a function of the autoclave exposure time. The hydration products formed within the first two hours were primarily $11 \&$ tobermorite [ $\mathrm{Ca}_{5}\left(\mathrm{SI}_{6} \mathrm{O}_{18} \mathrm{H}_{2}\right) \cdot 4 \mathrm{H}_{2} \mathrm{O}$ ]. Truscottite $\left[\mathrm{Ca}_{14} \mathrm{SI}_{24} \mathrm{O}_{58}(\mathrm{OH})_{8} \cdot 2 \mathrm{H}_{2} \mathrm{O}\right]$ in conjunction with a small amount of xonotlite $\left[\mathrm{Ca}_{6} \mathrm{Si}_{6} \mathrm{O}_{17}(\mathrm{OH})_{2}\right]$ was present as the major crystalline product after a 10-day exposure to the hydrothermal environment. Electron micrographs of fractured surfaces of 2-hr and 10-day 
specimens are shown in Figures 7 and 8 , respectively. In Figure 7 it can be seen that the morphology of the tobermorite yielded from a CLCM formulation composed of $56 \%$ bentonite fluid, $4 \%$ borax, $24 \%$ class $H$ cement, and $16 \%$ silica flour af ter exposure for $2 \mathrm{hr}$ at $300^{\circ} \mathrm{C}$ is charecterized by an interlocking structure of fine fibrous crystals. In contrast, the microcrystalline feature of the mixture of truscottite and xonotlite produced during the 10day autoclave exposure is an intermixture of fibrous plates and fine needles. The former are present in the form of truscottite crystals. The transformation of tobermorite into xonotlite and subsequently into truscottite yields an excess of silica and water at the elevated temperatures. These phase changes can be deduced from the pronounced reduction of the line intensity at $3.34 \&$ spacing which ascribes to the presence of unreactive silica. The silica remaining in the samples is very reactive and forms truscottite. Despite the work by Luke and Taylor ${ }^{16}$, there does appear transformation of xonotlite into truscottite. However, the xonotlite-truscottite transformation was still incomplete after a 10-day exposure. The formation to truscottite in the hardened CLCM seems to result in a strength decrease and enhanced water permeability. Truscottite, therefore, is a lowstrength binder. In contrast, a well-crystallized tobermorite formation would yield improvements in strength and a decrease in permeability. A xonotlite binder would be likely to yield properties intermediate between those of the tobermorite and truscottite. The observed strength decrease and permeability increase in the cementitious materials caused by the formation of truscottite are in agreement with results published by other authors. 17,18

Specimens autoclaved at $200^{\circ} \mathrm{C}$ and $250^{\circ} \mathrm{C}$ exhiblted progressive increases in strength with aging times of up to 10 days. However, the $250^{\circ} \mathrm{C} 2-\mathrm{hr}$ and $200^{\circ} \mathrm{C}$ 6-hr specimens did not develop sufficient strength to be measured. This was due to the remarkable retarding ability of the borax. The $2000^{\circ} \mathrm{C}$ 10-day specimens developed a strength of $3.8 \mathrm{MPa}$ ( $551 \mathrm{psi}$ ), the highest for 211 of the specimens tested thus far. They also yielded the lowest permeability values. 
As expected, XRD data for the $250^{\circ} \mathrm{C}$ aged samples indicated that tobermorite and silica were the major constituents after a 1-day exposure. After a 10-day exposure, xonotlite and silica were present as the major phase in conjunction with tobermorite and truscottite as minor products. The recrystallization from xonotlite to truscottite at $250^{\circ} \mathrm{C}$ was apparently much slower than for the samples at $300^{\circ} \mathrm{C}$. Thus, continued strength dévelopment could be anticipated by further autoclave curing. The XRD patterns at $200^{\circ} \mathrm{C}$ showed that the tobermorite formed during the 72-hr exposure was converted into well-crystallized tobermorite formulations af ter 10-day autoclaving. This binder appears to result in the high magnitude of strength development.

For the CLCM containing class $\mathrm{J}$ cement at $300^{\circ} \mathrm{C}$, the strength within the first two hours of autoclaving decreased gradually with increased exposure time. The strength of $\sim 0.5 \mathrm{MPa}(\sim 73 \mathrm{psi})$ for the 10-day aged specimens corresponds to a reduction of $\sim 71 \%$, as compared to that for the 2-hr autoclaved specimens. For the latter, the predominant reaction products were found to be a mixture of tobermorite and xonotlite in the presence of the unreactive silica as a minor phase. Extended autoclave time tended to favor the formation of truscottite. Xonotlite-truscottite transformation is likely to occur progressively during exposure periods of $\sim 72 \mathrm{hr}$, and simultaneously forms a small amount of scawtite $\left[\mathrm{Ca}_{7} \mathrm{Si}_{6}\left(\mathrm{CO}_{3}\right) \mathrm{O}_{18} \cdot 2 \mathrm{H}_{2} \mathrm{O}\right]$. This can be detected by the noteworthy decreases in the peak intensities at $3.08 \AA$ and $3.34 \&$ spacings which represent the xonotlite and silica, respectively, and the growth of a new peak at $\sim 3.00 \&$ which 1 s representative of the formation of scawtite. Since scawtite contains a small amount of $\mathrm{CO}_{2}$ in Its molecular structure, the formation is associated with the presence of $\mathrm{CO}_{2}$ in cements. 19 Extending the exposure time to 10 days results in an increase in the conversion rate to truscottite rather than xonotlite.

Figure 9 shows scroll-tubular crystals of truscottlte produced from a mixture of $56 \%$ bentonite fluld, $4 \%$ borax, and $40 \%$ class J cement af ter 10 days at $300^{\circ} \mathrm{C}$. From the standpoint of the space filling characteristics and 
morphological features of the microcrystalline forms, the truscottite structure produced from class $\mathrm{J}$ cement can be categorized as a porous binder in the form of thin plates $\sim 5 \mu$ in length, and 18 an inferior binder to that produced from class $\mathrm{H}$. The low density of the crystal formations relates directly to poor strength development and high water permeability. Again, an increase in the quantity of truscottite in the systems results in increased water permeability. At $250^{\circ} \mathrm{C}$, an increase in strength was noted over exposure periods ranging from 2 to $24 \mathrm{hr}$. Further exposures up to 3 days had little effect on strength, which remained at $\sim 1.7 \mathrm{MPa}$ ( $\sim 247 \mathrm{psi}$ ). Specimens tested after exposure for 10 days exhibited appreciable reductions in strength, due mainly to the formation of truscottite.

As discussed earlier, the major reaction products of class $\mathrm{H}$ and class $J$ systems at the same temperature and age are, respectively, xonotlite and truscottite. It appears that the xonotlite-truscottite transformation processes in class $J$ systems are much faster than those in class $H$ systems containing a large amount of silica flour. In the manufacture of commercially available class $\mathrm{J}$ cement, reactive silica is added to the cement. Therefore, the differences between the transformation rates in class $\mathrm{H}$ and class J systems may account for the characteristics of crystallinity, surface area, particle size, and concentration of silica added to cement.

As is evident from the decrease in permeability of samples autoclaved at $200^{\circ} \mathrm{C}$ and $250^{\circ} \mathrm{C}$ (see Figure 6 ), the class J CLCM slurries were converted Into high-density cements during exposure for up to 10 days in the autoclave. The basal spacings of $200^{\circ} \mathrm{C} 10$-day-aged specimens revealed the presence of a large amount of a well-crystallized tobermorite and a very small amount of scawtite and silica.

The above results suggest that the major factors determining the quality of the hardened CLCMs depend primarily on the C-S-H species formed under the hydrothermal conditions. The phase transformations of C-S-H groups produced in these particular CLCM systems over temperatures ranging from $2000^{\circ}$ to $300^{\circ} \mathrm{C}$ for 10 days are estimated to be in the order of tobermorite > 
xonotlite $>$ scawtite and truscottite. The strength retrogression and permeability Increase which occur gradually during the 10 -day exposure at $300^{\circ} \mathrm{C}$, therefore, were rationalized to be due to the transformation from tobermorite to xonotlite and from xonotlite to truscotite.

Bridging Additives

Although small fracture lost-circulation zones might be satisfactorily sealed using non-particulate-containing CLCM, plugging materials, it is also necessary to address the problem of sealing large fractures. To solve this important problem, the ability of commerclally avallable bridging materials used in conjunction with the CLCM formulations to plug various size fractures was estimated. In these studies, compressive strength and slot tests using an American Petroleum Institute (API) lost-circulation test cell that had been modified by Sandia National Laboratories, were undertaken to evaluate six bridging materials, fiberglass, crushed granular nuthulls, processed cane fibers, crushed miscovite mica flakes, shredded hardwood fiber, and shredded organic fiber. The first series of screening tests consisted of compressive strength measurements for CLCMs containing the various additives af ter exposure in an autoclave for 24 hours at $300^{\circ} \mathrm{C}$. These test results provide information on the hydrothermal stability of the bridging materials in strong alkaline environments and their ability to enhance the mechanical properties of the CLCMs at an early autoclaving age.

The specimens used contalned various concentrations of bridging additives in a CLCM formulation consisting of $56 \%$ bentonite fluid, $4 \%$ borax, $24 \%$ class H cement, and $16 \%$ silica flour. The fiberglass (supplied by the Owens-Corning Fiberglass (orporation) was $6.25 \mathrm{~mm}$ long, and contalned a chopped E-type glass. This type of glass generally disintegrates in strong alkalis at bolling temperature. 20 All the other additives were obtained from NL Barold Industries, Inc.

The compressive strengths of $300^{\circ} \mathrm{C}$ 2-hr-aged specimens as a function of bridging material, concentration are shown in Figure 10. As seen in the figure, the strengths of the hardened CLCMs depend primarily on the type and 
concentration of the particulates added to the CLCM. The highest strength obtained in this test series [3.7 MPa (537 psi)] was achieved by adding $\sim 0.2 \%$ fiberglass, which represents an improvement of $\sim 76 \%$ over that of the specimens without bridging materials. Further increases in the concentration of fiber glass resulted in strength reductions, probably due to poor compaction of the CLCM as a result of the increased slurry viscosity. Similar trends were obtained with the crushed granular nethull- and processed cane fiber-containing CLCMs. The other bridging additives evaluated did not produce strength increases, and are therefore considered unsultable. From these initial tests, It was concluded that fiberglass is the additive most effective in improving the mechanical properties of the autoclaved CLCMs.

As mentioned earlier, the fiberglass used is susceptible to chemical decomposition in strong alkaline media. Thus, it was anticipated that exposure of the fiberglass-containing CLCM in an autoclave at $300{ }^{\circ} \mathrm{C}$ would result in rapid deterioration of the mechanical properties because of disintegration of the fiberglass due to the alkaline nature of the matrix. To study the rate of deterioration, samples containing $0.5 \%$ fiberglass were exposed in the autoclave for up to 7 days at $300^{\circ} \mathrm{C}$. For comparison, control specimens were also examined.

The test results are listed in Table 3. An unexpected result was noted for the bridged specimens, namely, their strength as a function of exposure time was almost equal to that for the controls. The strengths for both materials increased within the first 24 hours, and then decreased slowly. After exposure for 7 days, the strength of the bridged specimen was 2.89 MPa ( 419 ps1), $16 \%$ less than that of the 2-hr-aged specimens. The controls showed a similar reduction.

XRD analyses of the specimens were performed to identify the reaction products. The results for both the unbridged and bridged CLCMs indicated the presence of tobermorite as a major phase within the first 2 hours and a mixture of xonotlite, tobermorlte, and truscottite after 7 days. The 
quantities of these hydration products in the bridged CLCMs were found to be approximately equal to those in the controls. This proves that the decrease in strength of the bridged specimens is due mainly to the phase transformation of C-S-H products rather than to the alkaline degradation of the fiberglass.

The energy-dispersive $x$-ray (EDX) spectrometer coupled with SEM was used to study the morphologicai features and chemical compositions of the fiberglass surfaces af ter exposure to $\mathrm{Ca}(\mathrm{OH})_{2}$ - oversaturated solutions for 24 hours at $300^{\circ} \mathrm{C}$. Figure 11 shows the microstructures and selected element counts of the fiber surfaces before and af ter exposure to the hot $\mathrm{Ca}(\mathrm{OH})_{2}$ solutions. The abscissa of the spectrum is the $x$-ray energy characteristic of the element present, and the intensity of a gross peak count is related directly to the amount of each element present. The fiberglass before exposure discloses a smooth surface nature, and the predominant element as shown in the EDX spectrum is the Si atom. Dramatic changes in the surface morphology of the fiber were observed on the samples exposed to the $\mathrm{Ca}(\mathrm{OH})_{2}$ solution. From Figure 11 (B), the surface was characterized by a microstructure consisting of fine needlelike crystals resembling tobermorite and xonotlite precipitated on the fiber surfaces. EDX exhibited that the count intensity of $\mathrm{Si}$ was appreciably lower than that of $\mathrm{Ca}$. In addition, $\mathrm{A}$ analysis of the strong alkaline solution after removal of the fiber indicated the presence of a large amount of silicate lons which were dissolved by alkaline degradation of the fibers. It is inferred that the silicate lons dissociated from the fiber surfaces react with $\mathrm{Ca}^{2+}$ lons in $\mathrm{Ca}(\mathrm{OH})_{2}-$ saturated aqueous media. This hydrothermal reaction leads to the precipitation of C-S-H compounds in the vicinity of the fiber surface. The precipitated reaction product was identified using XRD. The resulting $x$-ray lines could belong to the C-S-H phase which is known to form with a needle habit. The basal spacings at $3.09,2.98$, and $2.85 \&$ are ascribed to the possibility of the presence of tobermorite. When the fiber surfaces are completely covered with the well-crystallized tobermorite formations, the precipitated crystal layer may act as a protective layer which prevents the further alkaline disintegration of the fibers. Further work will be needed to 8 tudy in detall the interfacial nature and the bonding behavior between the precipitated 
crystals and the fiberglass. Nevertheless, the formed crystals serve a crosslinking function to connect the hydrated cement and the fiber. The bond strength at the cement matrix-fiber interfaces can be predicted to be at least as good as the strength of the crystals themselves. However, the interfacial shear strength is high because of the large solid matrix-fiber contect area.

\section{Slot Tests}

Since the maximum sealing pressures are observed to be highly variable, It is desirable to view these pressures relative to those that will actually occur in the wellbore. The wellbore pressure will have several components associated with it. The difference between the hydrostatic fluid head of the drilling fluid and the formation pore pressure is $>3.45 \mathrm{MPa}$ ( $500 \mathrm{psi}$ ) for many geothermal formations which are typically underpressured. The dynamic pressure associated with the fluid surge when the drill pipe is run into the hold is also of the order of $3.45 \mathrm{MPa}$ ( $500 \mathrm{psi}$ ) so that downhole pressures that are $6.89 \mathrm{MPa}(1000 \mathrm{psi})$ greater than the formation pressure are not uncommon. Hence, for a lost-circulation material to be useful in geothermal formations, it must be capable of sealing $6.89 \mathrm{MPa}$ (1000 psi) in the modified API tester. 21

Using the above information, slot tests were performed at room temperature to provide preliminary data regarding the ability of fiberglass to plug fractures of various sizes. In these tests, 150-mm-long slots were used in place of the standard API slots. As a result of the screening tests described earlier, the one bridging material evaluated in this test series was the $6.25-\mathrm{mm}-10 \mathrm{ng}$ chopped fiberglass. The concentration was varied in the range of 1 to $5 \%$. Test procedures were as follows: With the outlet valve closed and a slot of specified width in place, $3500 \mathrm{ml}$ of the fiber-mud mixture were poured into the reservoir. A piston to separate nitrogen-driving pressure from the drilling fluid mixture was then emplaced. The cap was then screwed onto the reservoir and the outlet valve was opened. With only hydrostatic pressure acting, the amount of fluid passing was recorded. The pressure on the fiber-mud slurry was then gradually increased at a rate of 
$\sim 0.03 \mathrm{MPa}(\sim 4.5 \mathrm{psi}) / \mathrm{sec}$ unt11 $6.89 \mathrm{MPa}$ (1000 psi) was reached. If the slot seal ruptured before this pressure was reached, the pressure at fallure was recorded, and the volume of effluent fluid was measured. If the seal held at $6.89 \mathrm{MPa}$ (1000 psi), the pressure was maintained for 10 minutes before the test was terminated.

Test results from these slurries at an ambient temperature of $27^{\circ} \mathrm{C}$ are summarized in Table 4. As indicated in the table, It appears that the sealIng ability of fiberglass is directly related to the concentration of fiber added to the mid slurry. When the crack was only $1.5 \mathrm{~mm}$ wide, a $1 \% \mathrm{fiber-}$ bridged slurry exhibited initial leakage at $0.14 \mathrm{MPa}$ ( $20 \mathrm{ps} 1$ ) and finally falled under a pressure of $0.69 \mathrm{MPa}(100 \mathrm{ps} 1)$. The pressure at fallure was increased by a factor of $\sim 7.0$ by the addition of $3 \%$ fiber. Although this substantially increased the mud viscosity, a 5\% Increase in the concentration resulted in no filtrate losses at the required sealing pressure of 6.89 MPa ( $1000 \mathrm{ps} 1)$. However, when this mixture was used in conjunction with a 4.0-mm slot size, a large filtrate loss occurred at a pressure of only 0.14 $\mathrm{MPa}(20 \mathrm{ps} 1)$. Consequently, the fiber length of $6.25 \mathrm{~mm}$ appears to be $\mathrm{in}$ sufficlent to fully seal large-size fractures. These results suggest that further slot tests are necessary to evaluate longer fibers. In addition, the plugging activity of hydraulic cement in conjunction with the bridging materials should be studied at temperatures elevated up to $300^{\circ} \mathrm{C}$.

\section{CONCLUSIONS}

Mixtures of hydraulic cement and water-based bentonite drilling fluids have a high potential for use in cementitious lost-circulation control materials (CLCM) In geothermal wells at temperatures up to $300^{\circ} \mathrm{C}$. Prior to the current BNL work, when cement was added directly to bentonite fluids, the viscosity of the resultant slurry and its short thickening time at elevated temperatures made it very difficult to pump. In our current work, it was determined that the addition of a borax $10 \mathrm{~mol}\left(\mathrm{Na}_{2} \mathrm{~B}_{4} \mathrm{O}_{7} \cdot 10 \mathrm{H}_{2} \mathrm{O}\right)$ admixture to the bentonite fluld before mixing with the cement, significantly acts to suppress the rate of complexations and bentonite hydrations and to retard the setting of the cement at elevated temperatures. The effectiveness of 
borax is due primarily to the $\mathrm{Na}^{+}$and $\mathrm{B}_{4} \mathrm{O}_{7}{ }^{2-}$ ions dissociated by hydrolysis of borax in the bentonite fluids. The compensation $\mathrm{Na}^{+}$lons are strongly chemisorbed on the S1-0- located between the intersheets of montmorilloaite. Once the negative silica sheets are neutrally balanced by $\mathrm{Na}^{+}$lons, the water-adsorbing capacity of the interlayers becomes yery small. Thus, Natsaturated intersheets contribute to restrain the cement-bentonite complex coagulation and reduce the swelling of bentonite, thereby decreasing the viscosity of the mud slurries. After incorporation with cement, large numbers of $\mathrm{B}_{4} \mathrm{O}_{7}{ }^{2-}$ counterions react rapidly with $\mathrm{Ca}^{2+}$ ions released from cement grains in colloidal bentonite-borax-cement-water phases. This nucleophilic attraction is associated with precipitation of a calcium-depleted silica gel and an impervious $\mathrm{film}$ of $\mathrm{Ca}^{2+}-\mathrm{B}_{4} \mathrm{O}_{7}{ }^{2-}$ complexation which covers the cement grain surfaces. These precipitations appear to provide an effective barrier which suppresses the propagation of cement hydrations. The great retarding activity of $\mathrm{B}_{4} \mathrm{O}_{7}{ }^{2-}$ at temperatures up to $300^{\circ} \mathrm{C}$ was proven by the dramatic extension of the thickening time of the slurry following the addition of borax. It was also observed that the borax acts to expand the hardened CLCMs. A $7 \%$ borax-treated slurry exhibited a linear expansion of $\sim 2.2 \%$, as compared to the shrinkage characteristics of the control slurry after autoclaving.

In hardened bentonite-cement-borax-water systems, the major factor controlling both the compressive strength and water permeability was found to be the $\mathrm{CaO}-\mathrm{SiO}_{2}-\mathrm{H}_{2} \mathrm{O}$ ( $\left.\mathrm{C}-\mathrm{S}-\mathrm{H}\right)$ species formed under the hydrothermal conditions. The qualitative ranking of $\mathrm{C}-\mathrm{S}-\mathrm{H}$ groups affecting the properties of the autoclaved specimens in the temperature range of $200^{\circ} \mathrm{C}$ to $300 \% \mathrm{C}$ was estimated to be in order of tobermorite > xonotlite > scawtite and truscottite. The well-crystallized tobermorlte responsible for the high-quality CLCM is essentially stable at a temperature around $200^{\circ} \mathrm{C}$. Increasing the temperature to $300^{\circ} \mathrm{C}$ leads to the tobermorite-xonotlite and xonotlitetruscottite transformations.

Without the addition of a bridging additive material to the CLCM, a loss of a large amount of the slurry can be expected before the cement sets if large fractures are encountered in a lost-circulation zone. The use of a bridging material could effectively reduce flow through or seal of the 
fracture until the CLCM hardens. Chopped fiberglass was identified as an effective material for this use. Al though the fiberglass used was susceptible to chemical disintegration in the hot alkaline solution, the C-S-H crystal formation precipitated by a nucleophilic reaction between the silicate lons dissolved from the fiber surface and the $\mathrm{Ca}^{2+}$ Ions from the cement under the hot alkaline conditions were shown to be effective as a protective layer to suppress further alkaline damage to the fiber and as a crossinking function which acts to improve the bond strength at the cement matrix-fiber interfaces. The ability of fiberglass to plug fractures of different sizes seems related to the concentration and the dimensions of the fiber added to the mud slurries.

\section{Acknowledgments}

The authors gratefully acknowledge Mr. G.E. Loeppke for performing the slot tests and helpful discussions with Dr. J.R. Kelsey and Mr. B.C. Caskey, all of Sandia National Laboratories. 


\section{References}

1. Sugama, T., Kukacka, L.E., Warren, J.B., and Galen, B.G., "BentoniteBased Ammonium Polyphosphate Cementitious Lost Circulation Control Materials" J. Mater. Sci., (in press).

2. Messenger, J.U., Lost Circulation, Penn Well Publishing Company, (1981).

3. Polk, G., Clements, W.R., and Simpson, G. Drilling with Mud for Geothermal, Presented at the Geothermal Resources Council, Geothermal Well Drilling and Complation Workshop, Reno, Nevada, May 24, 1982.

4. Messenger, J.U., U.S. Patent 4,183,199, 1ssued November 13, 1979.

5. Messenger, J.U., U.S. Patent $3,876,006$, issued April 8, 1975.

6. Damson, D.D., and Gains, W.C. Jr., "Bentonlte-Diesel 011 Squeeze", World 0il, p. 222, October 1953.

7. Goodman, M.A., Lost Circulation in Geothermal Wells: Survey and Evaluation of Industry Experience, SAND-81-7129, July 1981.

8. Fann Instrument, Dresser Industries, Inc., 1983.

9. Hoffman, U., Endell, K., and Wilm, D., Z. Krist. A86, 340 (1933).

10. Marshal1, C.E., Z. Krist. A91, 433 (1935).

11. Hendricks, S.B., J.Geol. 50, 276 (1942).

12. Powder Diffraction File, Inorganic Phases, Card 12-219.

13. Turriziani, R., Rio, A., and Collepardi, M., Ind. Ital. Chem. 35, 635 (1965).

14. Young, J.F., Tong, H.S., and Berger, R.L., J. Am. Ceram. Soc. 60, 193 (1977).

15. Thomas, N.L. and Double, D.D., Cem. Concr. Res. 11, 675 (1981).

16. Luke, K. and Taylor, H.F.W., Cem. Concr. Res. 14, 657 (1984).

17. Eilers, L.E., and Root, R.L., "Long Term Effects of High Temperature on Strength Retrogression of Cements," paper SPE 5028 presented at SPE 49 th Annual Fall Meeting, Houston, Texas, October 6-9, 1974. 
18. Gallus, J.P. and Pyle, D.E., "Performance of 011-Well Cementing Composition io Geothermal Wells" paper SPE 7591 presented at SPE 53 th Annual Fall Meeting, Dallas, Texas, October 1-3, 1978.

19. Kalousek, G.L., and Nelson, E.B., Cem. Coner. Res. 8, 283 (1978).

20. Owens-Corning Technical Information: Textile Fibers For Industry.

21. Hinkebein, T.E., Behr. V.L., and Wilde, S.L., Static Slot Testing of Conventional Lost Circulation Materials, SAND-82-1080, January 1983. 
Table 1

Properties of 60\% Bentonite Flufd - 40\% Class J Cement Slurry

Systens Treated Containing Various Adnixtures

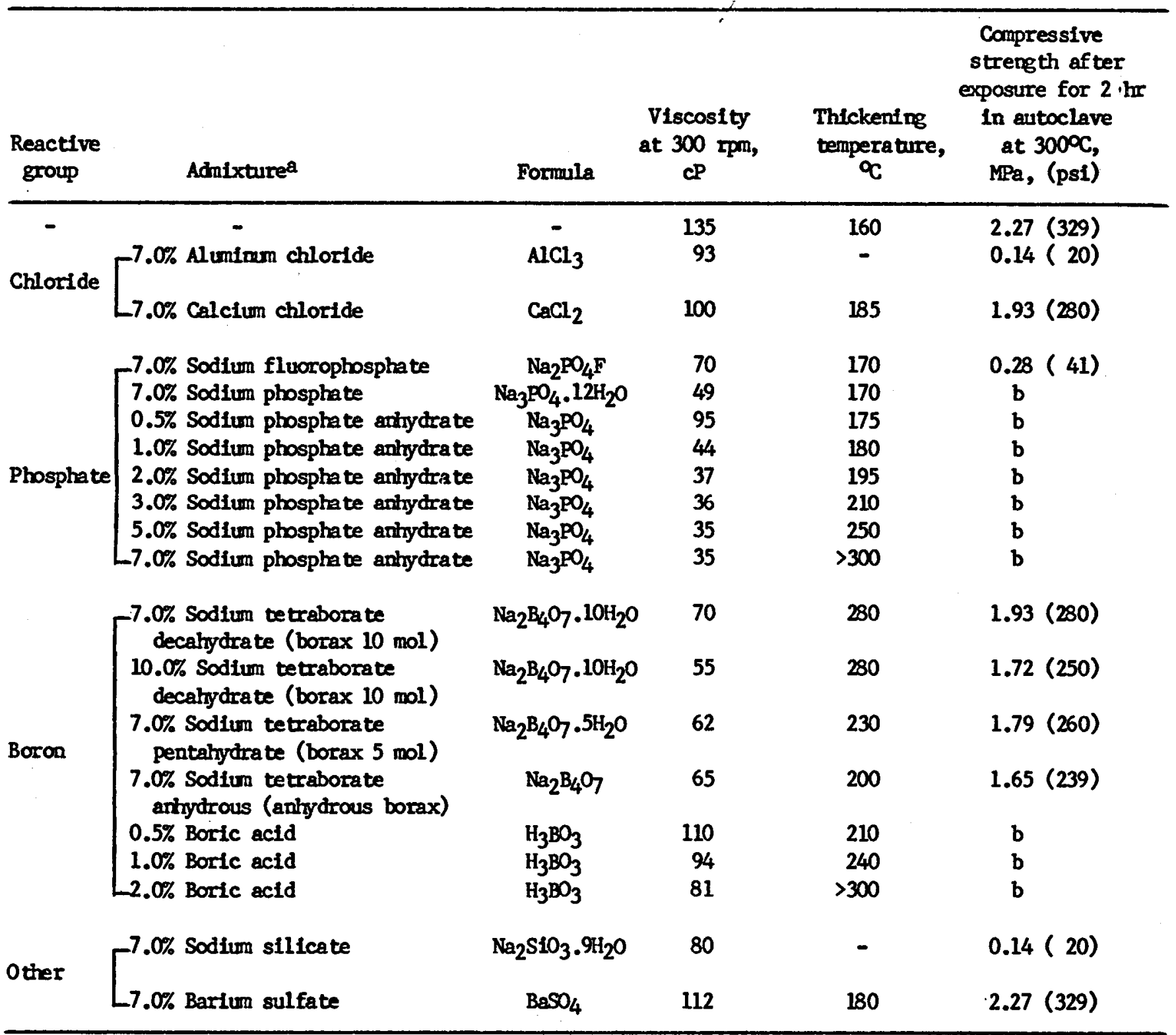

a \% by weight of bentonite-cement mix slurry.

b Too low to be measured. 
Table 2

$\mathrm{CaO}-\mathrm{SiO}_{2}-\mathrm{H}_{2} \mathrm{O}$ Phase Assemblages Crystallizing in Bentonite-Class $\mathrm{H}$ and $-\mathrm{J}$

Cement Systems as a Function of Autoclaving Temperatures and Tine

\begin{tabular}{|c|c|c|c|c|}
\hline System & $\begin{array}{l}\text { Temperature, } \\
{ }^{\circ}\end{array}$ & $\begin{array}{c}\text { Time, } \\
\text { trx }\end{array}$ & Phases Pres & Minor \\
\hline Class H cenent & 300 & 2 & 118 Tobermorite + Quartz & - \\
\hline Class H cement & 300 & 24 & $11 \AA$ Tobermorite + Xonotlite + Quartz & - \\
\hline Class H cement & 300 & 240 & Truscottite & Xonotlite + Quartz \\
\hline Class H cement & 250 & 24 & $11 \AA$ Tobermorite + Quartz & Xonotlite \\
\hline Class H cement & 250 & 240 & Xonotlite + Quartz & $11 \AA$ Tobermorite + Truscottite \\
\hline Class H cement & 200 & 72 & $11 \AA$ Tobermorite + Quartz & - \\
\hline Class H cement & 200 & 240 & $11 R$ Tobermorite & Quartz \\
\hline Class J cernent & 300 & 2 & $11 \AA$ Tobernorite + Xonotlite & Quartz + Scawtite \\
\hline Class $\mathrm{J}$ cement & 300 & 72 & Truscottite & Xonotlite + Scawtite + Quartz \\
\hline Class J cement & 300 & 240 & Truscottite & Xonotlite + Scawtite \\
\hline Class $\mathrm{J}$ cement & 250 & 24 & Xonotlite + Quartz & - \\
\hline Class $\mathrm{J}$ cement & 250 & 240 & Truscottite + Xonotlite & Scawtite \\
\hline Class $\mathrm{J}$ cement & 200 & 24 & $11 \AA$ Tobermorl te + Scawtite + Quartz & - \\
\hline Class J cement & 200 & 240 & $11 \AA$ Tobermorite & Scawtite + Quartz \\
\hline
\end{tabular}


Table 3

Comparison of Compressive Strength Between Unbridgéd and Glass Fiber Bridged CLCMs as a Function of Autoclaving Age at $300^{\circ} \mathrm{C}$

Compressive Strength, $\mathrm{MPa}$ (ps1), of Specimens After Exposure in Autoclave at $300^{\circ} \mathrm{C}$

\begin{tabular}{lcccc} 
& $2 \mathrm{hr}$ & 1 day & 3 day & 7 day \\
\hline Unbridged CLCM & $2.80(406)$ & $3.18(461)$ & $2.88(418)$ & $2.35(341)$ \\
Glassfiber-bridged CLCM & $3.46(502)$ & $3.95(573)$ & $3.30(479)$ & $2.89(419)$ \\
\hline
\end{tabular}


Table 4

Effect of Fiberglass Concentration on Sealing Ability

\begin{tabular}{cccr}
\hline $\begin{array}{c}\text { Fiberglass concentration, } \\
\%\end{array}$ & $\begin{array}{c}\text { Slot size, } \\
\mathrm{mm}\end{array}$ & $\begin{array}{c}\text { Sealing pressure, } \\
\text { MPa (psi) }\end{array}$ & $\begin{array}{r}\text { Accumulated } \\
\text { filtrate, } \\
\mathrm{ml}\end{array}$ \\
\hline 1 & 1.5 & 0 & 0 \\
1 & 1.5 & $0.14(20)$ & 200 \\
1 & 1.5 & $0.35(51)$ & 2750 \\
1 & 1.5 & $0.69(100)$ & 3200 \\
3 & 1.5 & $3.79(550)$ & 500 \\
3 & 1.5 & $4.82(699)$ & 3000 \\
5 & 1.5 & $6.89(1000)$ & 0 \\
5 & 4.0 & 0 & 0 \\
5 & 4.0 & $0.14(20)$ & 32000 \\
5 & 4.0 & $0.35(51)$ & 0 \\
\hline
\end{tabular}

a Maximum filtrate is $3500 \mathrm{ml}$. 


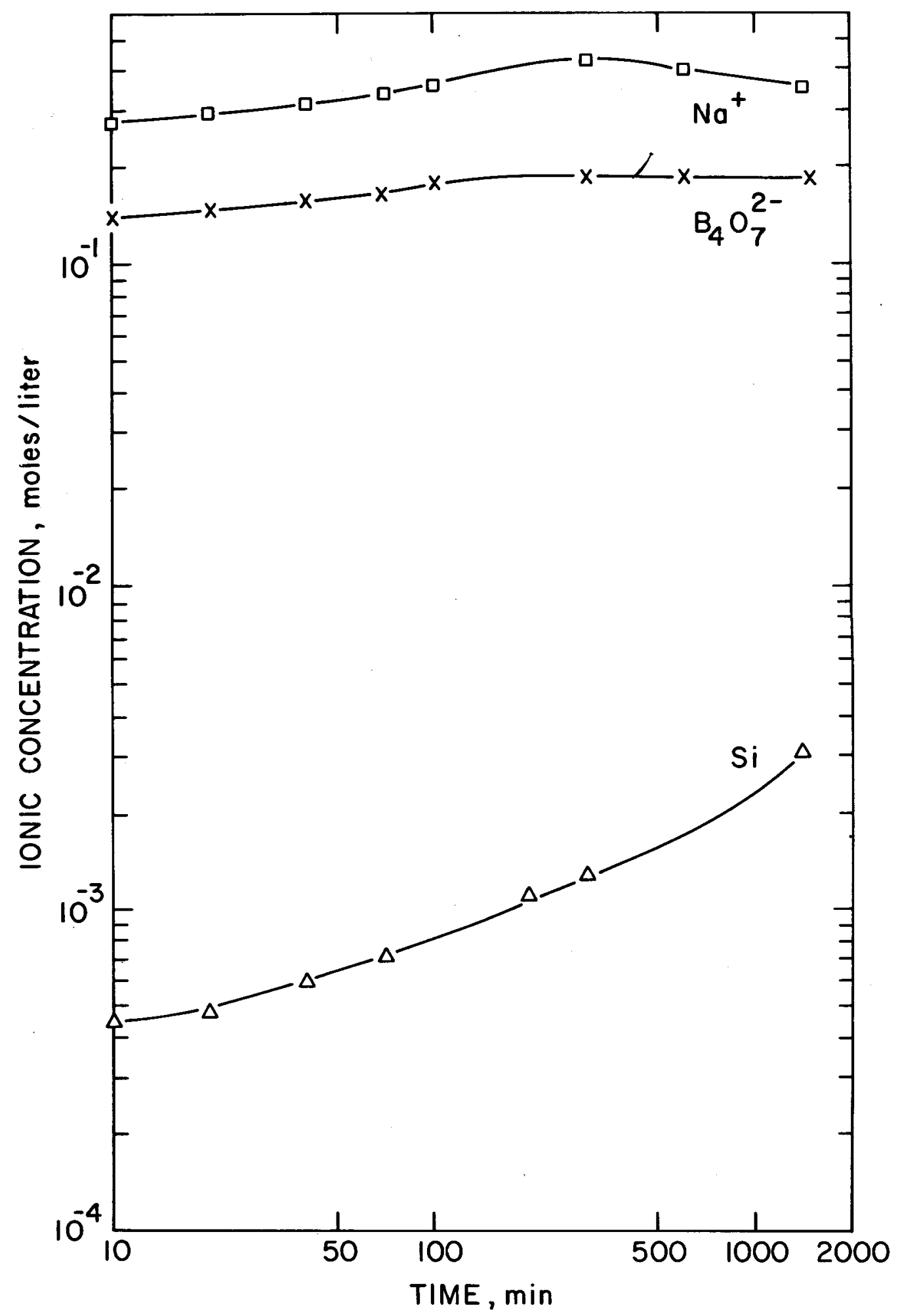

Figure 1. Changes in concentration of $\mathrm{Na}^{+}, \mathrm{B}_{4} \mathrm{O}_{7}^{2-}$, and silicate ions in the liquid phase of bentonite fluids mixed with borax. 


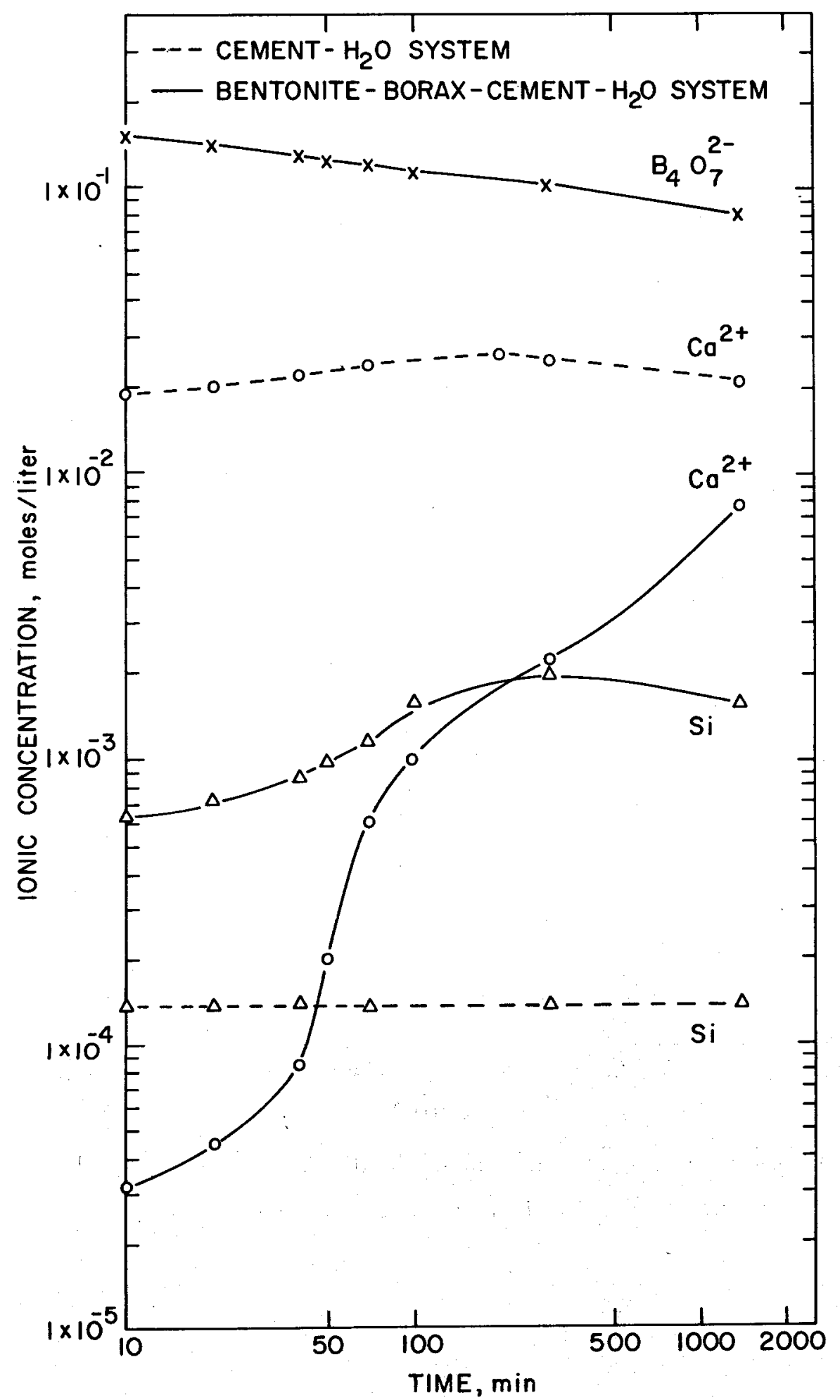

Figure 2. Ionic concentration in the extracted liquid of cement paste and borax-treated bentonite fluids containing cement. 


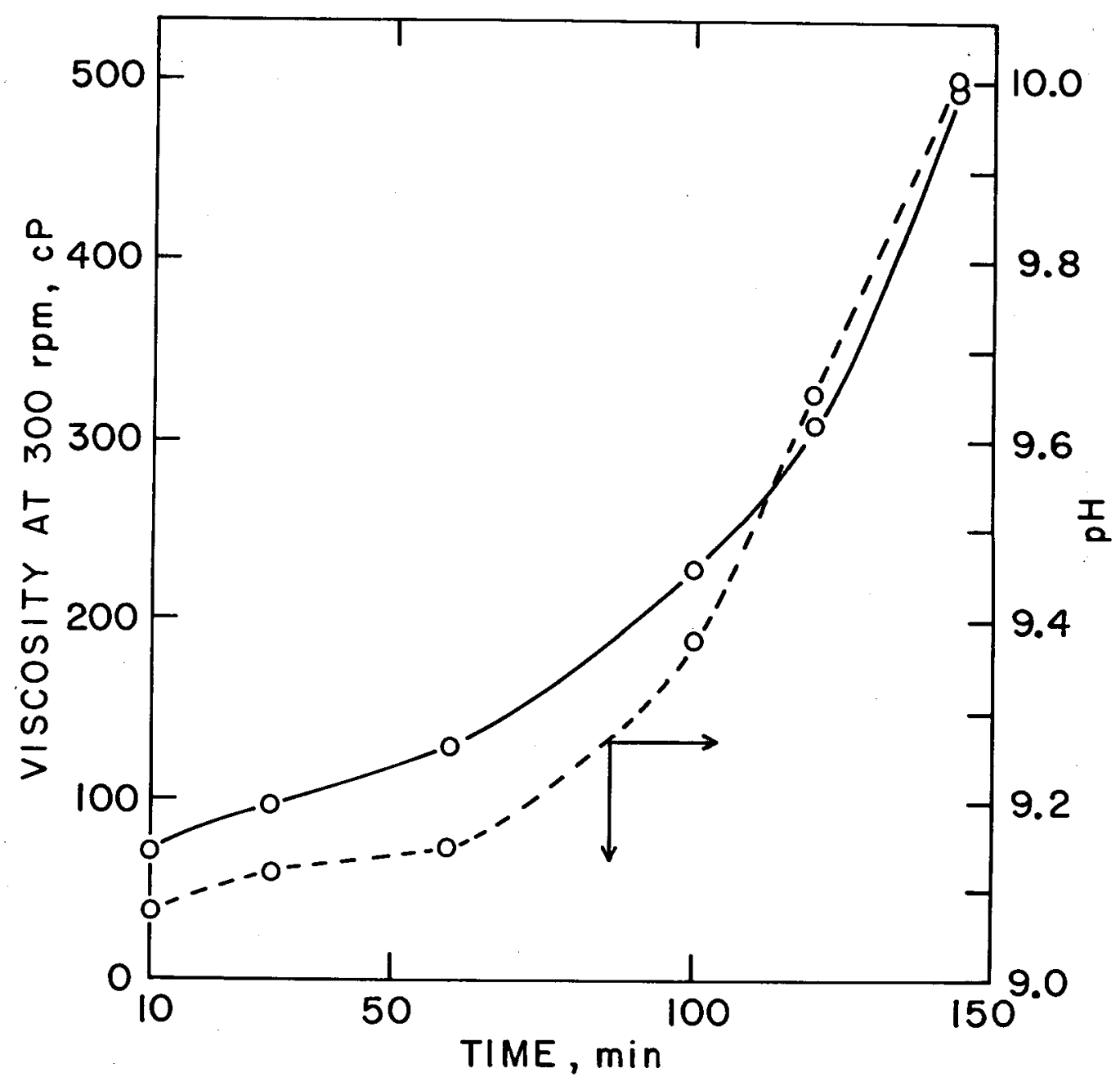

Figure 3. Variations in viscosity and $\mathrm{pH}$ of bentonite - borax - cement - water slurry systems as a function of stirring time. 



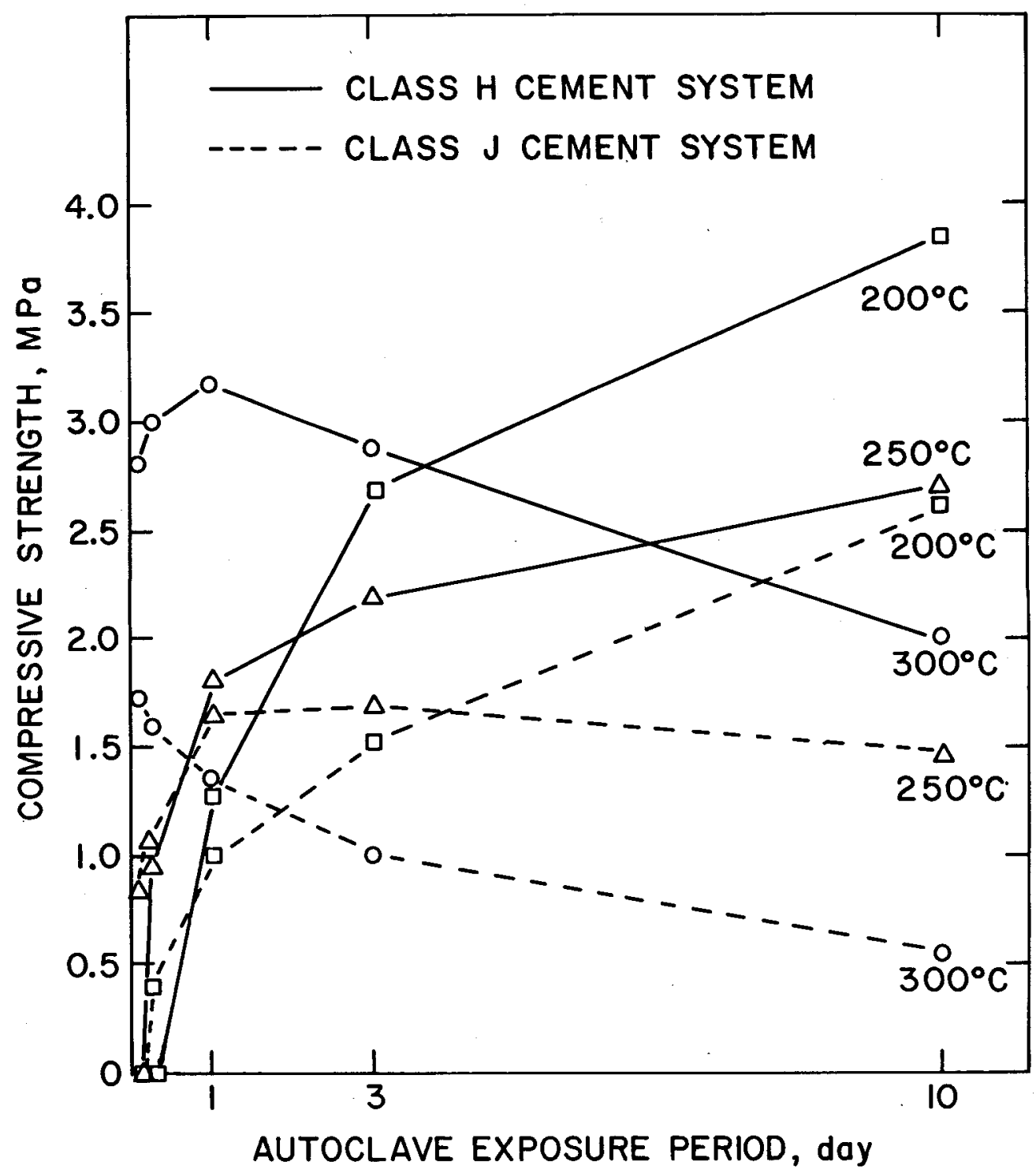

Figure 5. Changes in compressive strength of $7 \%$ borax-modified CLCMs as a function of exposure times at isothermal temperatures of $300^{\circ} \mathrm{C}, 250^{\circ} \mathrm{C}$, and $200^{\circ} \mathrm{C}$, $1 \mathrm{MPa}=145.1$ psi. 


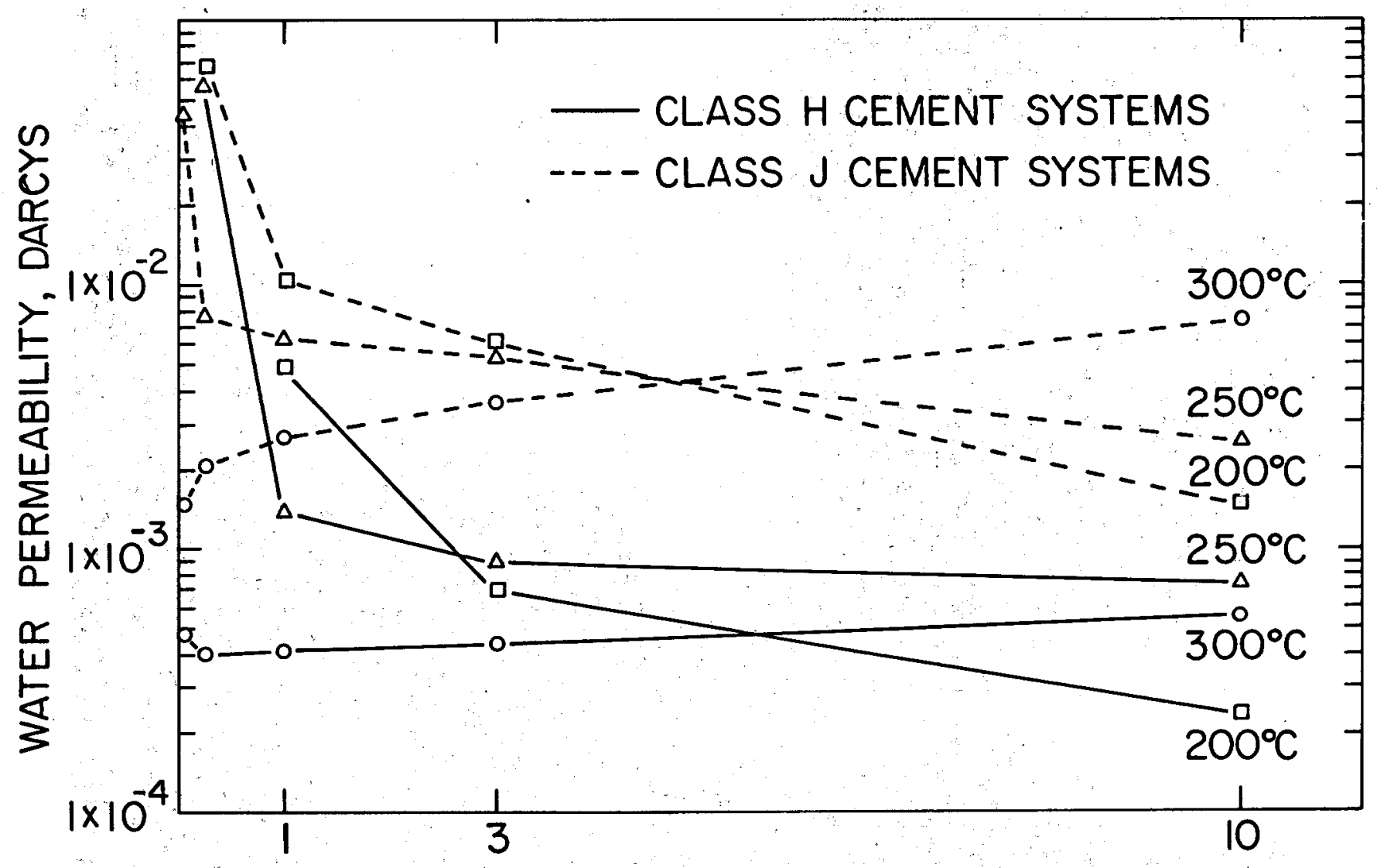

AUTOCLAVE EXPOSURE, day

Figure 6. Water permeability of CLCMs containing $7 \%$ borax as a function of exposure time at $300^{\circ} \mathrm{C}, 250^{\circ} \mathrm{C}$, and $200^{\circ} \mathrm{C}$. 


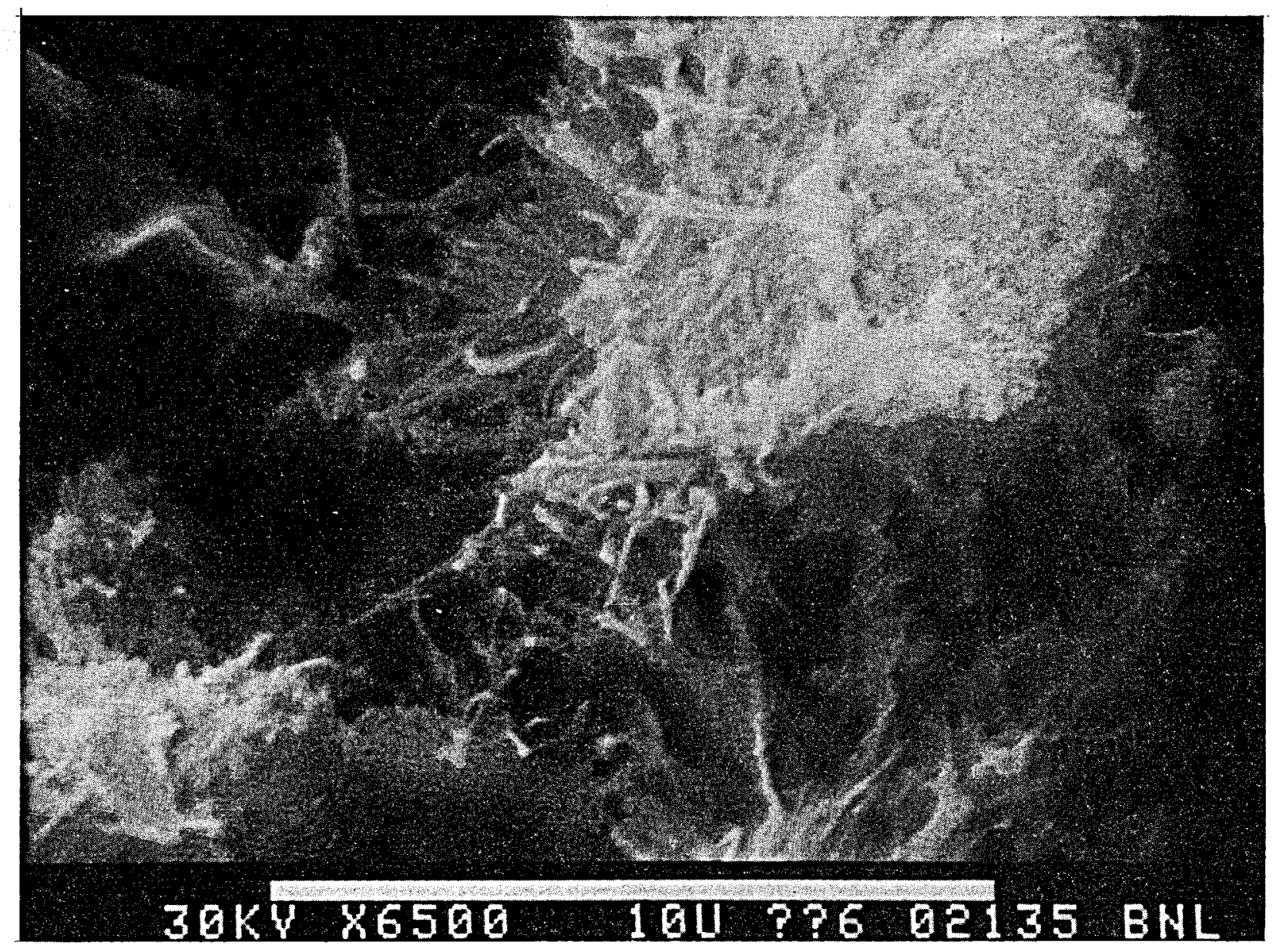

Figure 7. Electron micrograph of tobermorite formed in two hours at $300^{\circ} \mathrm{C}$ from bentonite-borax-class $H$ cement silica flour - water systems. 


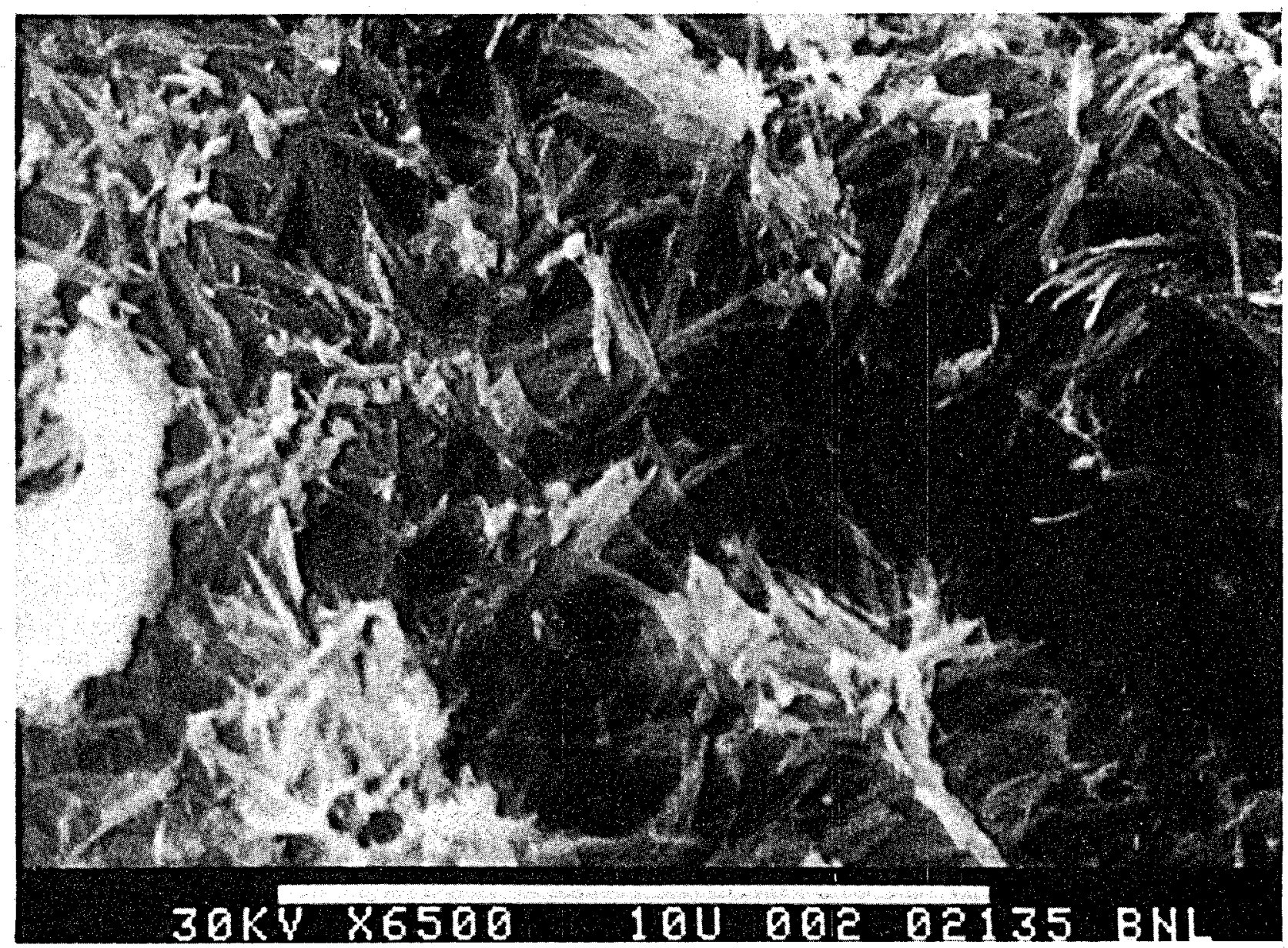

Figure 8. Fibrous plates of truscottite blended with fine needles of xonotlite produced from class $\mathrm{H}$ systems autoclaved at $300^{\circ} \mathrm{C}$ for 10 days. 


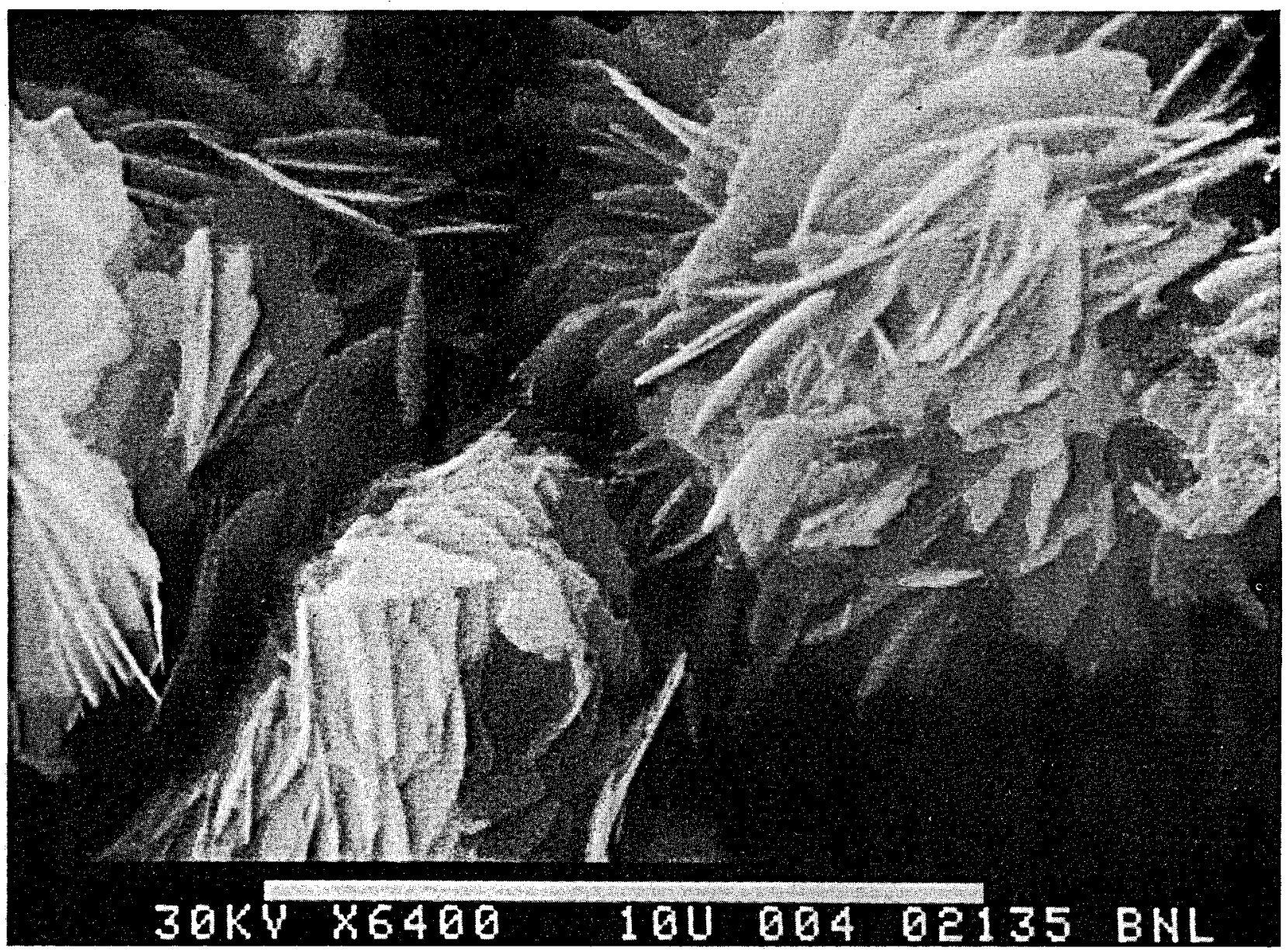

Figure 9. Scroll-tubular crystals of truscottite formed in 10 days at $300^{\circ} \mathrm{C}$ from bentonite-borax - class J cement-water systems. 


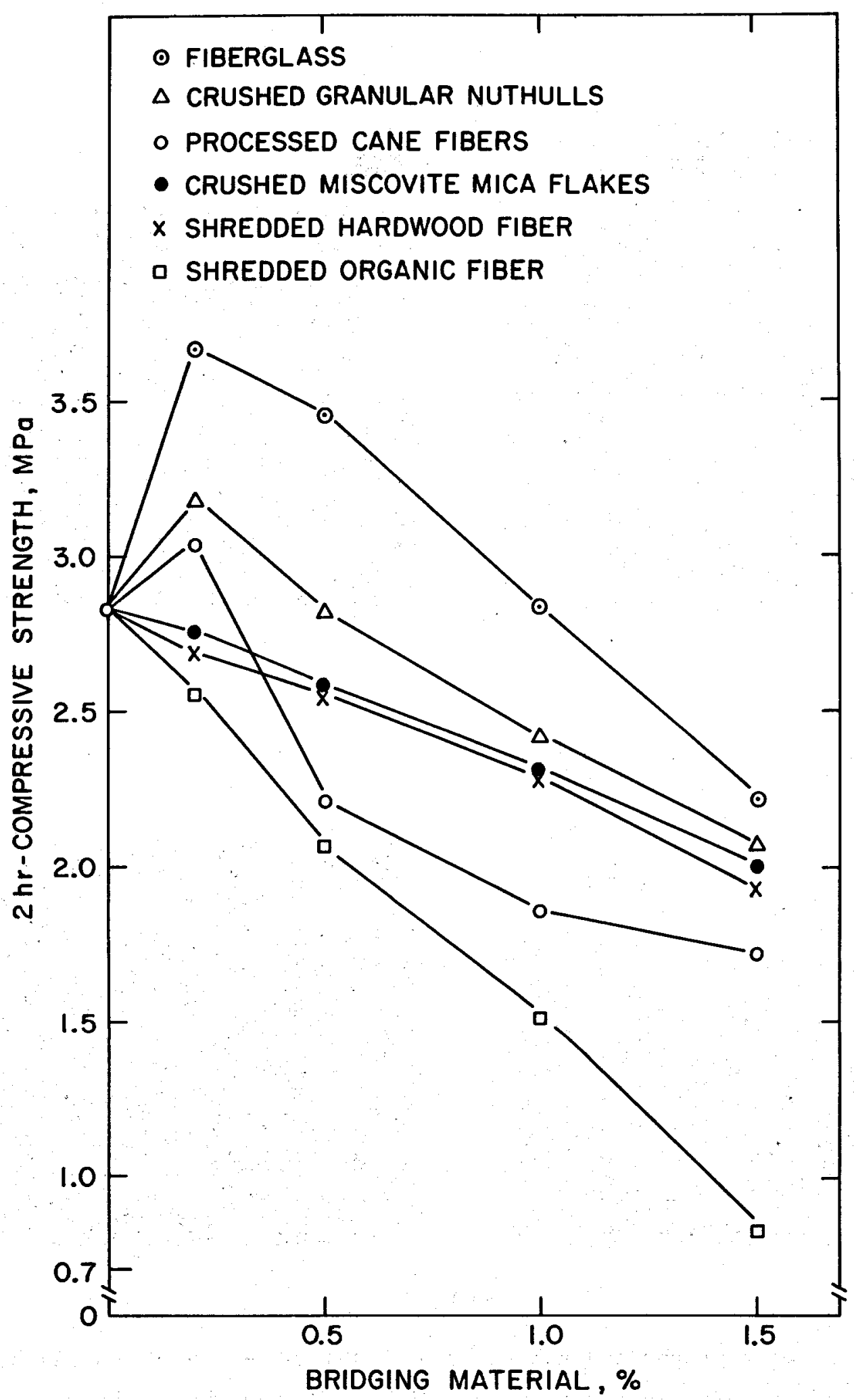

Figure 10. Changes in compressive strength of $300^{\circ} \mathrm{C} 2-\mathrm{hr}$ specimens as a function of concentration of various bridging additives, $1 \mathrm{MPa}=145.1$ psi. 

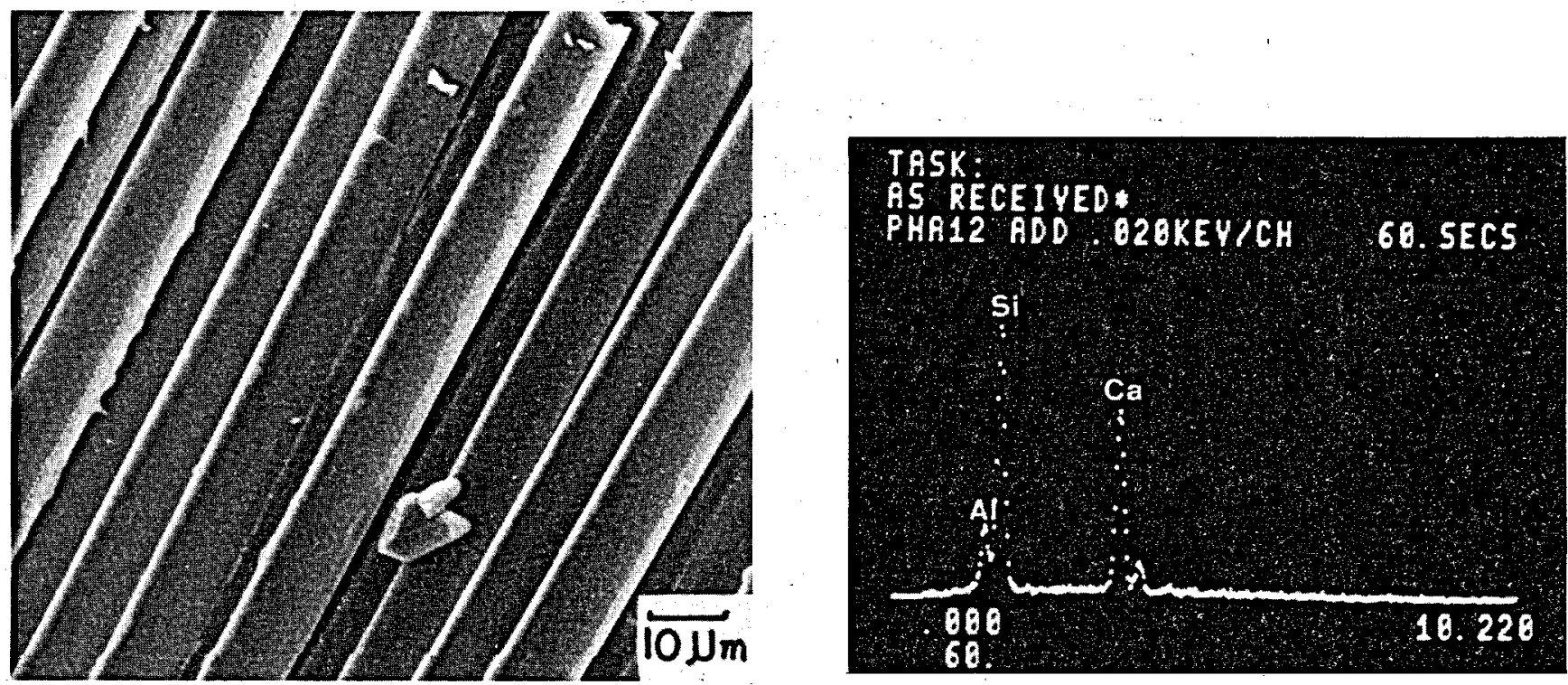

(A)
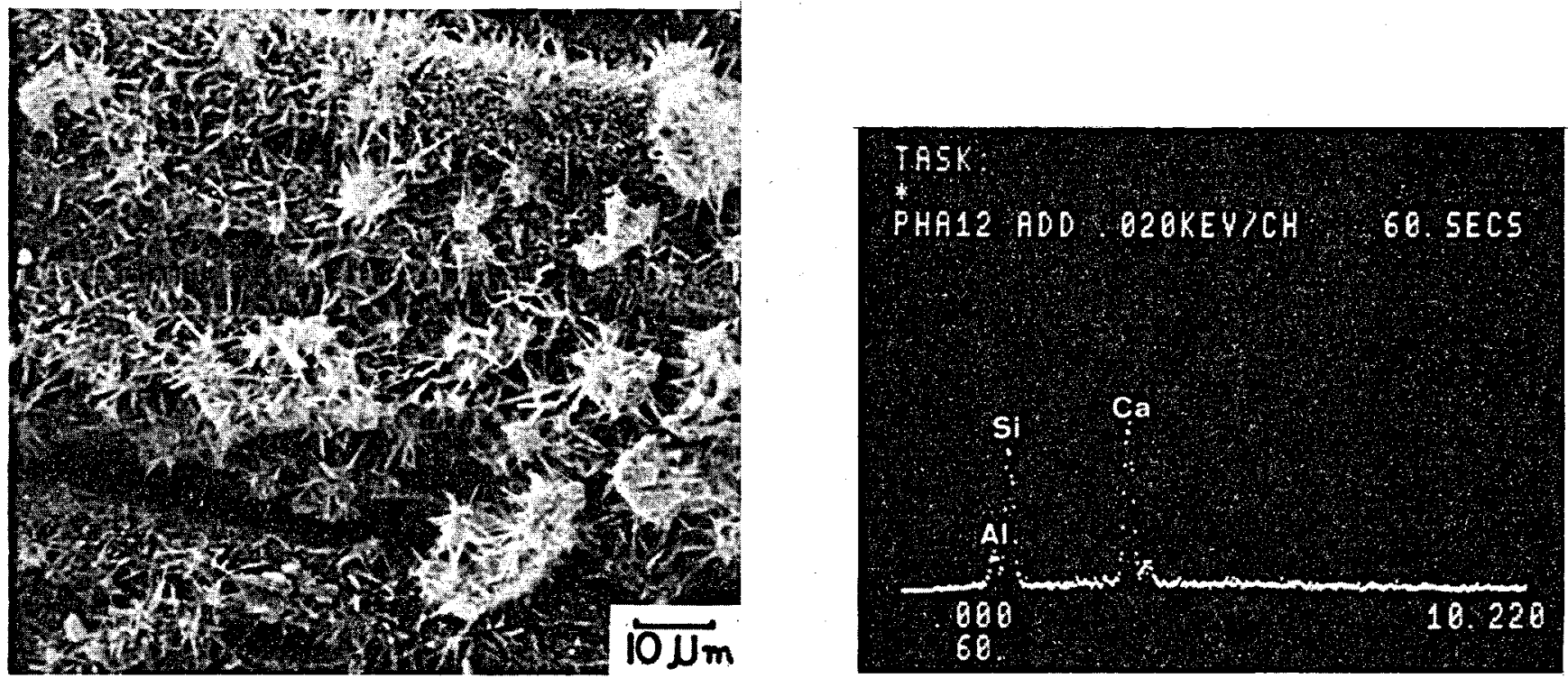

(B)

Figure 11. SEM micrographs and EDX spectra of fiberglass surfaces (A) before and (B) after exposure to a $\mathrm{Ca}(\mathrm{OH})_{2}$ solution for 24 hours at $300^{\circ} \mathrm{C}$. 